Yıldız, Ö., Işıldar, P. / Journal of Yasar University, 2020, 15/59, 407-425

\title{
2016 Türkiye Turizm Krizi Üzerine Bir İnceleme
}

\section{Turkish Tourism Crisis: An Overview}

\author{
Özay YILDIZ, Dokuz Eylül Üniversitesi, Türkiye, ozay.yildiz@deu.edu.tr \\ Orcid No: 0000-0002-0777-8574 \\ Pınar IŞILDAR, Dokuz Eylül Üniversitesi, Türkiye, pinar.isildar@deu.edu.tr \\ Orcid No: 0000-0001-7667-9951
}

\begin{abstract}
Öz: Turizm küresel bir etkinliktir ve turist pazarları dış etkenlere karşı aşırı duyarlıdır. Turistik talep de, lüks tüketim sonucu fiyat değişimlerine karşı esnek özellik gösterir. Bu nedenlerle doğal afet, salgın, ekonomik kriz, terör, politik istikrarsızlık ve savaş gibi tetikleyici olaylar, turist sayılarında ve turizm gelirlerinde öngörülemeyen dalgalanmalara neden olur. Turizm gelirinin turist ağırlayan ülke ekonomisi için önemi doğrultusunda, kayda değer düșüssler turizm krizleri olarak değerlendirilir. Krizin ă̆ırlı̆̆l, süresi ve yayılacağı coğrafi alan her ne kadar tetikleyici olayların türü, boyutu, tekrarl ya da sürekliliği ve medya ilgisi gibi belirleyicilere bağlı olsa da, önceden kestirilemeyebilir. İşletme ve hedef bölgeler krizi sürecin doğal bir parçası olarak kabul etmek, değișime çabuk uyum sağlayacak önlemleri almak ve pro-aktif planlamalarını geliștirmek zorundadırlar. Bu çalıșmada, tetikleyici unsurların 2016 krizine etkisi kronolojik olarak analiz edilmiş, alan yazını ve benzer olaylar ile klyaslanmıştır. Türkiye'de, özellikle 2014'ten itibaren, komşu ülkede iç savaș, sı̆̆ınmacı sorunu, terör saldırıları, darbe girișimi, önemli turist gönderen ülkelerle yașanan gerilimler ve yayınlanan seyahat uyarıları gibi kriz tetikleyici unsurlar yaşanmıştır. Sonuç olarak, 2016 yılında Türkiye turizmi en ağır krizini yaşamıştır. Uluslararası turist girişlerinde dörtte bir, turizm gelirinde ise üçte bir oranında kayıp yașayan Türkiye turizmi, dls ilișkilerin düzelmesi ve güvenliğin sağlanması ile önemli bir toparlanmaya girerek, 2018 yılında krizi turist sayısı anlamında atlatmıştır. Yakın ve komşu ülkelerden girişler ve Türk vatandaşları krizden daha az etkilenmiş görünmektedir. Ancak turizm geliri, uluslararası turizmden alınan pay ve turistik işletme yatırımları gibi göstergeler bakımından 2018 sonu itibariyle kriz atlatılamamıştır. Acil dönemde krize tepki olarak gerçekleşen fiyat indirimleri, uzun dönemde pazar baskisina neden olarak turist başına gelirin daha da düşmesine neden olmuştur.
\end{abstract}

Anahtar Sözcükler: Türkiye Turizmi, Turizm Krizi, Kriz Tetikleyici Unsurlar, Turizm Ekonomisi

JEL Sinfflandirmast: L83, Z30, Z32

Abstract: Tourism is a global business and tourist markets are highly susceptible to external factors. Tourism demand is highly elastic since it involves luxury consumption. Therefore, triggering events including natural disasters, outbreaks, economic crises, terror, political instability and war cause significant and unforeseeable fluctuations in international tourist arrivals and tourism receipts. In accordance with the importance of tourism in the economy of the receiving country, significant drops are referred to as tourism crises. The gravity, duration and geographical spread depend on the type, dimension, repetition and persistence of the triggering events as well as media attention, but are difficult to foresee. Establishments and destinations should acknowledge crisis as a natural part of the process, take immediate precautions to adapt to change and implement pro-active planning. This paper aims to analyse the effect of triggering events on 2016 tourism crisis in Turkey in comparison with the relevant literature and similar examples. In 2016, Turkish tourism suffered its gravest tourism crisis in its history, as a result of a series of triggering events that started as early as 2014, including civil war in a neighbouring country, refugee issues, terror attacks, attempted coup, strained external relations with important tourist generating countries and travel advisories. Turkish tourism lost one fourth of its tourist arrivals and one third of its tourism receipts, but expressed a significant resilience and recovered by 2018 in terms of tourist arrivals, as a result of restored external affairs and internal security. Regional and Turkish arrivals seemed less affected by the crisis. However, indicators including tourism receipts, market share in international tourism and tourism investments have not recovered from the crisis by the end of 2018. Reactional price reductions caused market pressure and further reduced income per tourist.

Keywords: Turkish Tourism, Tourism Crisis, Crisis Triggering Events, Tourism Economics

JEL Classification: L83, Z30, Z32

\section{Giriş}

Turizm, artık çok iyi bilindiği üzere dünyanın en büyük ve en hızlı büyüyen iş alanlarından biridir. Dünyada toplam katma değerin \%10'unu, dışsatımın \%7'sini ve hizmet dışsatımının \%29'unu oluşturan turizm, yılda yaklaşık 1,7 trilyon Amerikan doları dışsatım geliri yaratmakta, ayrıca çalışan her 10kişiden biri turizm endüstrisinde istihdam edilmektedir (UNWTO 2019). Turizm gelirinin ülke ekonomilerine görünen katkısından dolayı, sürekli olarak yeni hedef bölgeler ortaya çıkmaktadır (İçöz vd., 2009). İletişim ve ulaşım teknolojilerindeki sürekli gelişim sonucu, turizm küresel bir hal almıştır (Göçen vd. 2011). Turizm endüstrileri, ya da "birbirleriyle karşılıklı etkileşim halinde bulunan, birbirlerine bağımlı hizmet sağlayıcılarının oluşturduğu uluslararası ă̆” (Maser ve Weiermair, 1998), turist gönderen ve ağırlayan ülkelerin politika ve ekonomisini etkilediği gibi, bunlardan da büyük ölçüde etkilenmektedir (Henderson 2007). Dünyada uluslararası turist girişlerinde yakın geçmişte yıllık ortalama $\% 4,2$ büyüme görülmekle birlikte, 2017 'de $\% 7,2018$ 'de de $\% 6$ artış yaşanmıştır (UNWTO 2018; UNWTO 2019). Bu artış, 2010'da yapılan projeksiyonun da üzerindedir.

\section{Makale Gecmissi / Article History}

Başvuru Tarihi / Date of Application Kabul Tarihi / Acceptance Date

(C) 2020 Journal of Yaşar University. Published by Yaşar University. Journal of Yaşar University is an open access journal.

There is no conflict of interest or ethical concern regarding this publication. 
Yine de turizm verileri, kimi zaman öngörülemez biçimde dalgalanmalar yaşamaktadır. Kendine has özellikleri sonucu, uluslararası turist girişleri (ITA) ve turizm geliri (ITR), herhangi bir uyarı olmaksızın belirgin düşüşler yaşayabilmektedir. Büyük oranda düşen talebe karşı acil ve onarıcı bir eylem olarak görülen fiyat indirimleri ve pazar basklsı sonucu genellikle turizm gelirinin toparlanması daha uzun sürer (Sönmez ve Graefe, 1998). Bu durum, örnek olarak Türkiye'de 1999 Marmara depreminden (TUIK 2017) ve dünyada 2009 uluslararası ekonomik krizinden sonra da görülmüsstür (UNWTO 2016). Türkiye'de 1999 yılında yaşanan Marmara depreminin ardından, 1998'de 9.752 .697 olan yabancı ziyaretçi sayısı 7.487.285'e, turizm geliri ise 7.808.940 dolardan 5.203.000 dolara gerilemiştir. 2000 senesinde yabancı ziyaretçi sayısı 10.428.153'e yükselerek toparlanma yaşanmış gibi görünse de, turizm gelirimiz 7.636.000 dolar ile 1998'in altında kalmıştır (T.C. Kültür ve Turizm Bakanlığı 2017; TUIK 2017). Bu durum, tablo 1’de de görülebilmektedir.

Tablo 1. 1998 - 2018 Uluslararası (Net) Turist Girişleri ve Turizm Geliri (Türkiye):

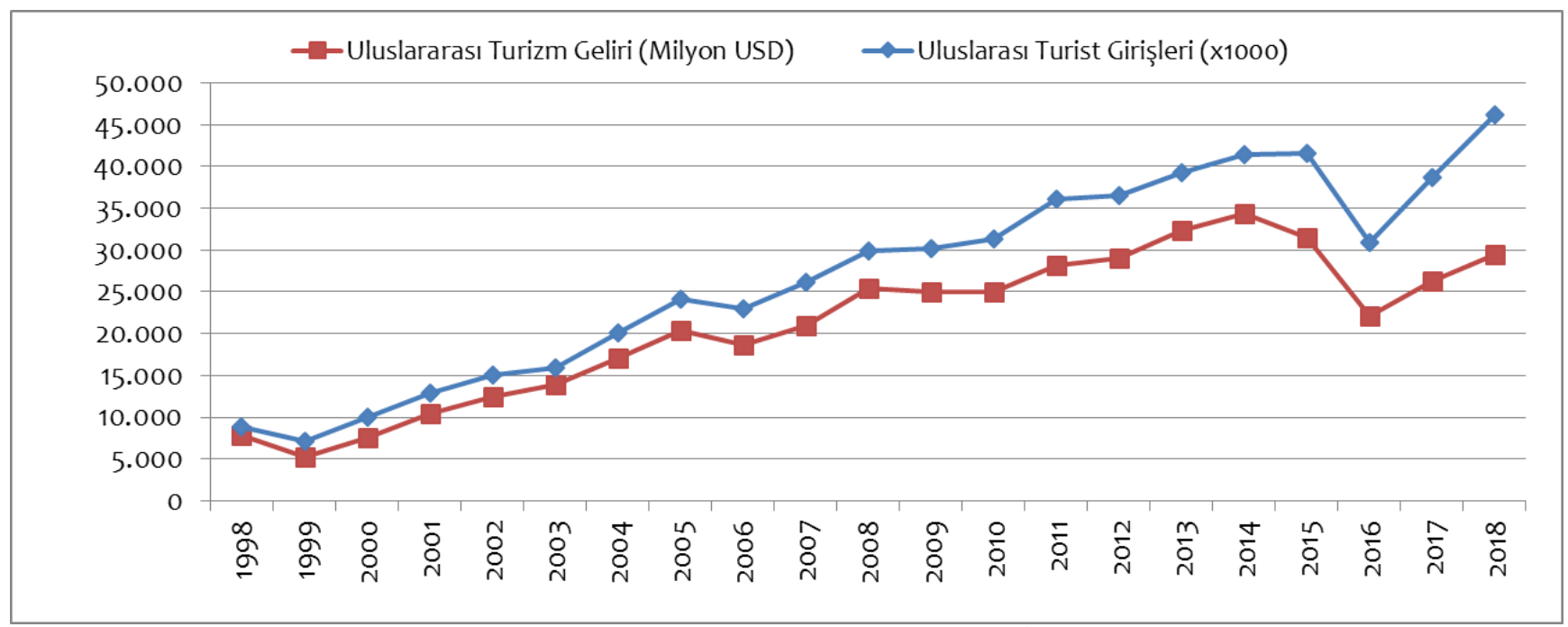

Kaynak: TC Kültür ve Turizm Bakanllğg, 2019; TUIK 2019

Son yılların en önemli uluslararası finansal krizi 2009'da yaşanmıştır. Yaşanan ekonomik belirsizlik ve domuz gribi salgını nedeniyle uluslararası turist sayıları ve gelirinde gözle görülür düşüş yaşanmıştır. Uluslararası turist sayısı 928 milyondan \%4,2 düşüşle 892 milyona, uluslararası turizm geliri de \%5,7 düşüşle 885 milyar dolara gerilemiştir. 2008'in ikinci yarısından itibaren başlayan düşüş, 2009'un son aylarına kadar sürmüş, 2010'un ilk ayları artış kaydetmiştir. Turizm geliri ise ancak 2011'de 2008'i aşmıştır. 2009'da Avrupa, Amerika ve Ortadoğu \%5 ve üzeri düşüş yaşarken Afrika ise \%5,1 artış yaşamıştır (UNWTO 2019). Türkiye'de 2009'da uluslararası ziyaretçi sayısında 1 milyonluk bir artış görülse de, turizm gelirinde kayıp yaşanmıştır (T.C. Kültür ve Turizm Bakanlığı 2019; TUIK 2019). Bu durum, Tablo 2'de de görülebilmektedir. 
Yıldız, Ö., Işı1dar, P. / Journal of Yasar University, 2020, 15/59, 407-425

Tablo 2. 1998 - 2018 Uluslararası Turist Girişleri ve (Reel) Turizm Geliri (Dünya):

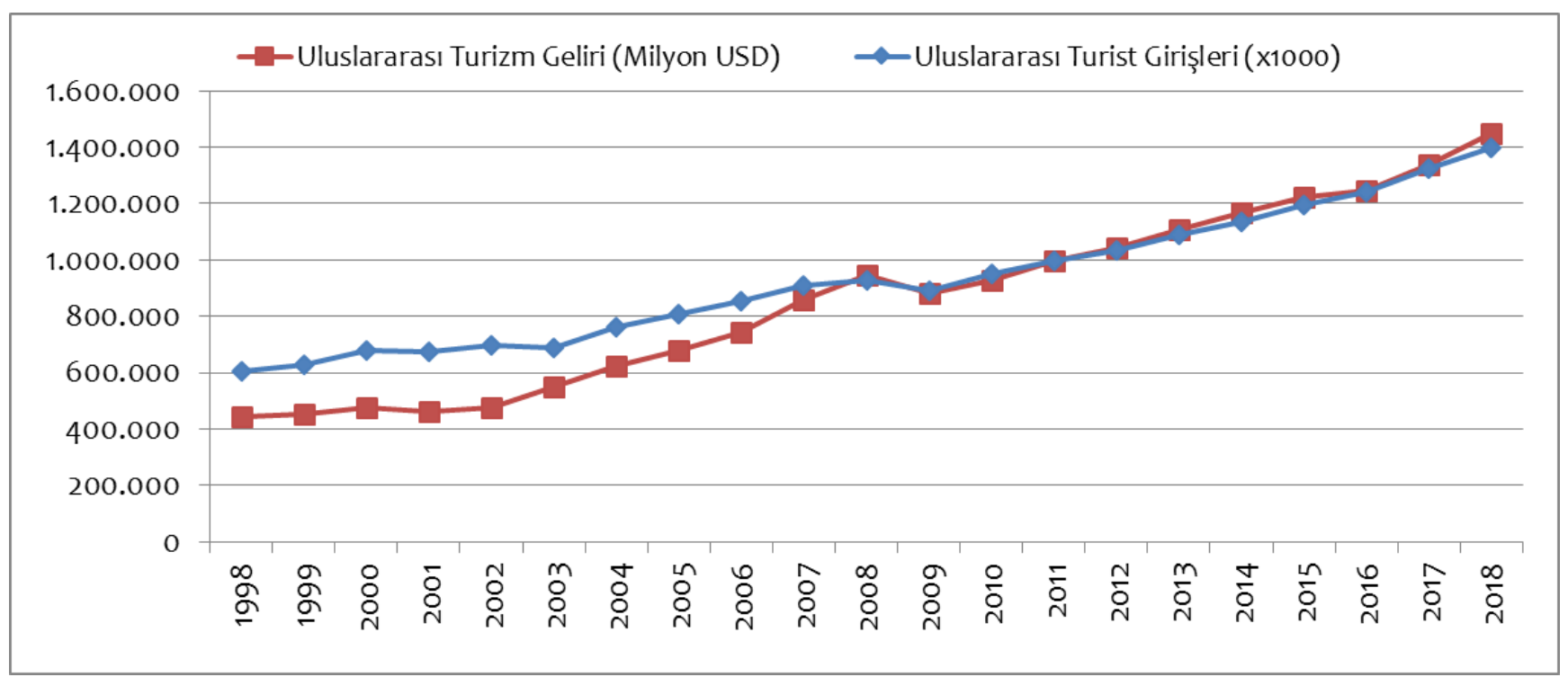

Kaynak: UNWTO, 2019

Böyle düşüşlerin nedenlerinden bir tanesi, büyük oranda turizmin içsel ya da dişsal değişkenlere karşı aşırı duyarlı olmasından kaynaklanmaktadır. Böylesi bir unsur, ya da "tetikleyici olay" (Henderson 2007), hedef bölge ya da turizm işletmesinin uyum sağlayamayacağı denli ani, zararlı ve yıkıcı koşullara yol açtığında, bir turizm krizinden söz edilebilir (Faulkner 2001; Henderson 2007; Göçen vd. 2011). Çoğu durumda, ya bir doğal afetin, ya da insan eliyle yaratılmış bir krizin turizm krizinin öncülü olduğu görülür (Henderson 2007; Hajibaba vd. 2015). Turizmin "uluslararasılaşması”(küreselleşmesi), aynı zamanda seyahat halinde olan bireylerin de artık küresel risklere duyarlı olduğu, turizm krizlerinin de küresel sonuçlarının olduğu anlamına gelmektedir (Nordkvist Öman 2016).

Turizm krizlerini doğru yorumlamak, kriz önleme, kaçınma ya da kriz ardından toparlanma stratejilerini geliştirebilmek, turizm işletmeleri ve turist kabul eden ülkeler için yaşamsal önem taşımaktadır. Bu çalışmada, öncelikle kriz ve turizm ilişkisi irdelenmiş, genel olarak turizmde hangi unsurların, niçin krize neden olduğu üzerinde durulmuştur. Ardından kaynaklarına, belirleyicilerine ve özelliklerine göre kriz türleri ve turist pazarlarının krizlere tepkisi incelenmiş̧ir. Bu veriler, krizin doğru biçimde yönetilebilmesi için gereklidir. Son bölümde, Türkiye turizminde 2016 krizine neden olan tetikleyici unsurlar kronolojik biçimde verilmiş, uluslararası turist girişleri ve turizm geliri istatistikleriyle karşılaştırılarak yorumlanmıştır.

\section{Turizm Krizlerinin Türleri}

İçsel unsurlardan kaynaklanan işletme ölçekli krizler, örnek olarak aşırı rezervasyon sonucu konaklama hizmetinin sunulamaması, hemen hemen her zaman işletme ya da endüstrilerin çok az kontrol edebildiği (ya da hiç edemediği) dişsal unsurlardan kaynaklanan krizlerden daha az kayda değer olacaktır (Henderson 2007; Kozak vd. 2007; Hajibaba vd. 2015). Konuyla ilgili geniş yazın içinde, tetikleyici olayların ve turizm krizlerinin belirleyicilerinin sınıflandırılmasına ve bunlarla ilgili risklerin belirlenmesine yönelik bir eğilim bulunmaktadır. Ne var ki, krizin şiddeti genelde çok sayıda unsur tarafından belirlenmekte ve her zaman güvenilir olarak öngörülememektedir.

Dışsal nedenlerden doğal afetler, en ani, öngörülemez ve yıkıcı sonuçlara ve turistlerin can güvenliğine yönelik doğrudan risklere neden olmaktadır (Faulkner 2001). Afetin büyüklüğü doğal olarak krizin şiddetini ve toparlanma sürecini belirlemektedir. Tahmini 200.000 kişinin yaşamını kaybettiği 2004 Hint Okyanusu deprem dalgası (tsunami) felaketindeki gibi turizm ve genel alt ve üstyapı ciddi oranda etkilenmediyse de, doğal afetlerin hedef bölgenin imajını ve turizm verilerini kısa erimde etkilediği görülmüștür. Bir diğer can güvenliği riski, doğal ya da insan eliyle gerçekleşen salgın hastalıklar da, daha uzun süreli etkileri olan ve geniş bir coğrafi alana yayılabilen sonuçlar verebilmektedir (Kozak vd. 2007; Göçen vd. 2011). 2001'de Birleşik Krallık'ta yaşanan şap hastalığı salgını bölgesel etkilere neden olmuşken (Ritchie 2004), SARS salgını çok daha geniş bir korkuya ve turist sayılarında düşüşe neden olmuştur(Kozak vd. 2007). Yine 2006'da Türkiye’de görülen kuş gribi salgınının medya ve kamuoyunda büyük panik ve korkuya neden olması sonucu, uluslararası turist girişlerinde \%4,4, turizm gelirinde \%8,5 oranında düşüş yaşanmıştır (TUIK, 2017). Kriz 2007'de atlatılmıştır (bkz. Tablo 1).

Finansal krizler hemen hemen her durumda turizm endüstrisini doğrudan etkilemekte (Maser ve Weiermair 1998) ve 2009'da açıkça görüldüğü gibi küresel sonuçlara bile neden olabilmektedir. Ekonomik belirsizlik ve kriz zamanlarında, 
tüketicilerin marjinal tasarruf eğilimi artar ve lüks tüketimde, dolayısıyla turizm harcamasında düşüş görülür (Olalı ve Timur, 1988; İçöz 2005). Bu koşullarda seyahate çıkanlar da daha kısa, ucuz ve yakın seçeneklere yönelirler (Henderson 2007). Düşen talebe tepki olarak turistik ürün fiyatları düşmekte ve bu da sonuç olarak turist başına gelir ve toplam turistik geliri düşürmektedir.

Politik kaynaklı tetikleyici olaylar da turistler için can ve mal güvenliği riskleri yaratır. Politik istikrarsızlık, terörizm, bölünme, savaş gibi insan eliyle yaratılmış krizler ve hatta bunların olasılığı, seyahati önleyerek krizden etkilenen bölgedeki turizmi temelinden sarsabilmektedir (Henderson 2007). Turistik seyahat ancak özgür, barışçıl ve bağımsız koşullarda gerçekleşebilir; turist gönderen ve ağırlayan ülkeler arasındaki ilişkilerin gerilmesi bile turist akımını azaltır (Olalı ve Timur 1988).

Özel olarak terörizm, hedef bölge imajı için yıkıcı ve turistlerin can güvenliğini tehlikeye atan sonuçlara neden olur. Özellikle teröristler tarafından politik anlamda daha önemli olarak algılandığı ve daha geniş uluslararası medya ilgisi (aleniyet) yarattığı için "yumuşak hedefler" olarak görülen turistlerin de terör eylemlerinin kurbanı olduğu durumlar daha yıkıcı olmaktadır (Sönmez ve Graefe 1996; Sönmez ve Graefe 1998; Henderson 2007; Nordkvist Öman 2016).Turizm, boyutu, çeşitliliği ve eriminden dolayı açık bir hedef olmaktadır. Turistlerin çoğu kolaylıkla tanınabilmektedir ve ünlü çekim merkezleri, kumsallar, oteller ve ulaşım terminalleri gibi belirli alanlarda büyük sayılarda toplanma eğilimindedir. Turist sayılarında ve turizm gelirinde meydana gelen bir düşüş aynı zamanda ekonomiyi zayıflatmakta ve sosyal gerilimlere neden olabilmektedir. Bu da hükümetlere baskı oluşturmakta ve teröristlerin genel istikrarsılık yaratma amacına destek olmaktadır (Henderson 2007).

Örnek olarak, Mısır'ın Luxor Tapınağında 1997'de gerçekleşen, 58 turistin yaşamını yitirdiği terör eyleminin Mısır'ın hedef bölge imajı ve turizm verileri üzerinde yıkıcı etkileri görülmüştür. Olayın hemen ardından toplu iptaller ve doluluk oranlarında düşüş yaşanmış, 1998 'de turist sayılarında $\% 14$, gelirlerde $\% 45$ düşüş gözlenmiştir. Artırılan güvenlik önlemleri, indirimler ve tanıtım kampanyaları sonucu kriz ancak 2000 yılında atlatılmıştır (Henderson 2007).

Terörist etkinliğin yoğunluğu ile ilgili yayınlanan istatistiklere göre, 1970'ler ve 1980'ler arasındaki eylemlerde hızlı bir artış görülmüştür. Daha sonra eylemlerin hacmi düşmekle beraber, ölüm ve yaralanmaların sayısı artmıştır. 1990 ve 2000 'li yıllarda ana hedefler ticari $(\% 30)$, devlet $(\% 8)$, diplomatik $(\% 7)$, askerî $(\% 1,5)$ ve diğerleri $(\% 53)$ olmuştur. Bir diğer eğilim de bireysel saldırıların boyutunda ve yayılma alanında görülen genişleme olmuş, bu da saldırıların izole olaylar değil örgütlü bir komplonun parçası olduğu ve "herkesin savunmasız olduğu” hissini uyandırmıştır (Henderson, 2007).

Yakın geçmişin en büyük uluslararası terör saldırısı (ve turizm krizi) 11 Eylül 2001'de ABD'de yaşanmıştır. ElKaide'ye bağlı saldırganlar tarafından kaçırılan uçaklar, New York'ta bulunan Dünya Ticaret Merkezi'nin iki kulesine, ardından ABD Savunma Bakanlığı karargâhı Pentagon'a intihar saldırısı düzenlemiştir. Saldırılar sonucunda 19 hava korsanı dâhil 2.996 kişi hayatını kaybederken, 10 milyar doların üstünde maddi hasar meydana gelmiştir (CNN 2016). Saldırının ardından çok ciddi terör karşıtı önlemler alınmıştır. Turizm alanında, havaalanları ve uçaklarda hava polisi, güvenli kokpit kapıları, silahlı pilotlar, asker, pasaport kontrolleri, biyometrik yöntemler gibi çok yoğun güvenlik önlemlerine ek olarak ABD hava sahası uzun süre hava trafiğine kapatılmıştır (Henderson 2007). Ardından yaşanan iptal ve iflaslara ek olarak, turistlerin güvenlik algısının kaybı sonucu uluslararası turist akımlarındaki artış görünür biçimde yavaşlamıştır. ABD, vatandaşlarını özellikle iç turizme teşvik etmiştir. Uluslararası turist sayıları dalgalanma yaşarken, turizm gelirlerinde gözle görülür bir düşüş yaşanmıştır (bkz. Tablo 2).

11 Eylül olaylarının ardından 2004'te Madrid'de banliyö trenlerine eşzamanlı olarak gerçekleştirilen bombalı saldırılar sonucu 191 kişi hayatını kaybederken 2000'den fazla kişi yaralanmıştır. El Kaide olayları üstlenmişsir (Henderson 2007). Ardından 7 Temmuz 2005'te Londra'da üçü metro ve biri otobüste olmak üzere 4 intihar bombalı eylemde 52 kişi yaşamını kaybetmiş, 300'den fazla kişi de yaralanmıştır (CNN 2017).

Bu yıllarda El Kaide'ye bağlı mücahitler veya amacına sempati duyanlar giderek daha görünür hale gelmiştir. Bu örgütlerden biri Güneydoğu Asya'da Jemaah İslamiyah (JI) adıyla kendini göstermektedir. Bu gruplanmalar, 1990'ların ortalarından beri Amerika, Avrupa, Ortadoğu ve Uzakdoğu'da bir dizi saldırıdan sorumlu olmuşlardır. Batı karşıtı duygular belirleyici bir özelliktir ve bu 2003 'teki Irak savaşı ve bunun kötü sonuçlarıyla daha da kabarmıştır. Bu düşmanlık uluslararası turizme de yönlenmiştir ve El Kaide "düşman personel ve uluslararası turistlerin suikastı" amacını kabul etmiştir. Belirli hedefler olmasalar da, turistler de kamuya açık alanlarda, aynı zamanda ulaşım, konaklama veya rekreasyon tesislerinde yapılan saldırılarda risk altındadır (Henderson 2007).

Savaşlar ve iç savaşlar da turist akımlarını engellemektedir. Turistler doğal olarak istikrarsızlık ve savaş durumundaki hedef bölgelerden kaçınırken, devletler de çabalarını turizm dışında, daha acil alanlara yoğunlaştırırlar. Sonuçlar 90'larda Hırvatistan ve komşu ülkelerdeki gibi bölgesel (Henderson 2007), ya da 1991 Körfez Savaşı’ndaki gibi küresel olabilir (Sönmez ve Graefe 1998).

2010'da başlayan “Arap Baharı”, Ortadoğu ve Kuzey Afrika ülkelerinde toplumsal başkaldırı, huzursuzluk ve politik istikrarsızlığa neden olarak hedef bölgenin güvenlik imajını zedelemiştir. Bölge ülkelerinin turist sayıları ve turizm gelirleri önemli dalgalanmalar yaşamıştır. 2013 yılında Mısır \%18, Irak \%20 turist kaybetmiş̧tir. 2015 yılında tüm Kuzey Afrika bölgesi turist sayısı bakımından \%11,7 ve turizm geliri bakımından \%9,8 kayıp yaşamıştır (UNWTO 2017). Irak’taki politik belirsizlik, Mısır'da askeri darbe, Suriye'deki iç savaş gibi olumsuzluklar sonucu tüm bölgenin imajı etkilenmiş ve turizm krizi yaşanmıştır. Bu sürecin uzantısı kabul edilebilecek terörist gruplar, uluslararası alanda ve gelişmiş merkezlerde, çok sayıda can kaybına neden olan eylemler gerçekleştirmiştir (Sönmez ve Graefe 1998). 
Son olarak devlet yönetimine askeri müdahale ve darbeler de hedef ülke ve kimi durumlarda komşuları için turizm krizlerine neden olmaktadır. Turist pazarlarında kaybolan güvenlik algısı da uzun erimli düşüşlere neden olabilir. 2014'te Tayland'da yaşanan askeri darbe ve ardından gelen seyahat kısıtlamaları sonucu ülkeye giriş yapan turist sayısı $\% 6,5$, turizm geliri \%8 azalmış, kriz 2015’te atlatılmışırı (UNWTO 2017).

Sonuç olarak, özellikle havayolu taşımacılığının gelişmesi, rekabet sonucu uçak bileti fiyatların düşmesi, ağ iletişimi ve ağ rezervasyonu, işletmelerin uluslararası hale gelmesi ve turistlerin etkin iletişimi gibi etkenler sayesinde yakın geçmişte turizm sürekli ve (görece) istikrarlı bir büyüme yaşamıştır. Ancak yine aynı nedenlerle, genelde kendini turist sayıları ve turizm geliri istatistiklerinde önemli düşüşler biçiminde gösteren turizm krizleri de yaşanmıştır ve yaşanmaya devam etmektedir. Daha fazla sayıda can kaybına neden olan, daha beklenmedik yerlerde gerçekleşen, daha geniş alanlara yayılan ve medyanın (aşırı) tepkisiyle daha fazla kişi tarafından duyulan terör eylemleri ve salgın hastalıklar gibi tetikleyici olaylar doğrudan turist akımını baskılamanın yanında, turistlerin güven algısını da zedeleyerek "kimse güvende değil" korkusuyla turist sayılarında belirgin düşüşlere de neden olmaktadır.

\subsection{Turizm Krizlerinin Belirleyicileri ve Sonuçlart}

Belirleyiciler söz konusu olduğunda, olay ya da olayların sıklığı ve süresi en yüksek öneme sahip görülmektedir. Örnek olarak tek ve yalıtılmış bir terör eylemi daha kısa erimli krizlere neden olmaktayken, politik kargaşa, darbe, savaş ya da savaş tehlikesi gibi süreğen olaylar daha uzun erimli sonuçlar yaratır (Göçen vd. 2011; Saha ve Yap 2013). Riskin kalıcılığı ve coğrafi büyüklüğü de krizin uzunluğunu ve şiddetini belirler (Henderson 2007). Kriz sürekli bir durum aldığında, turizm talebinin tamamen yitirilmesi tehlikesi bulunur (Göçen vd. 2011).

Turist ağırlayan ülkeler için önemli bir sonuç, daha yakın ülkelerden gerçekleşen turist akımının, daha uzak ülkelere göre daha az etkilenmesidir. Bu durum, 2000 - 2009 arasında, SARS salgını, Hint Okyanusu deprem dalgası ve Bali bombalamaları sonucu Malezya'nın yaşadığı turizm krizinde görülmüsstür. Yakın turist gönderen ülkelerden gelen turist sayısı göreceli olarak istikrarlı kalmışken, daha uzak ülkelerden girişlerde belirgin bir düşüş yaşanmıştır (Ooi vd. 2013). Bu durum uzaklık, yanlış bilgilenme ve yabanc1lık sonucu gerçekleşmektedir (Henderson 2007).

Bir diğer boyut olan yaygın can güvenliği tehlikesi algısı ya da "genelleme etkisi” sonucu, örneğin 90'larda çok sayıda yerel hedef bölgenin savaştan etkilenmemesine karşın tüm Hırvatistan'ın savaştan etkilendiği şeklinde bir algı oluşmuştur (Henderson 2007). Bu etki daha da belirgin olarak İsrail - Filistin krizinde yaşanmıştır. Yalnızca bir bütün olarak İsrail değil, tüm Ortadoğu riskli olarak algılanarak turist sayısında düşüş yaşamıştır (Beirman 2002). Bu yayılma etkisi, komşu ülkelerde karşılıklı bir düşüşe neden olabileceği gibi, Yunanistan - Türkiye gibi ikame edilebilirlik durumunda bir komşu ülkenin yararına da olabilir (Saha ve Yap 2013).

Turizm krizlerinde gerçek belirleyiciler asıl öneme sahipken, nihai olarak medyanın olaya ilgisi ve yaklaşımı ile ağızdan ağıza iletişim hedef bölgenin imajı ve turist sayılarındaki dalgalanmalar üzerinde belirleyici olmaktadır(İçöz 2001; Kozak vd. 2007). Turizm pazarları hedef bölgenin imajını, büyük ölçüde tetikleyici olaylar hakkında kitlesel medyada yapılan haberler doğrultusunda değerlendirirler (Saha ve Yap 2013; Seabra vd. 2014; Nordkvist Öman 2016). Turist gönderen ülkelerin resmi seyahat uyarısı yayınlaması turist sayılarını doğrudan etkilemektedir. En kötü durumlarda turistlerin (ve diğer vatandaşların) tahliyeleri ya da ülkelerine geri gönderilmeleri hedef bölgenin imajını daha da yıpratır (Henderson 2007).

Kriz zamanlarında haberlerin inandırıcılığı konusunda da (gerçekleri çarpıtma, olmuş gibi gösterme) tartışmalar yaşanmaktadır (Sönmez ve Graefe 1998). Kitlesel medya, gerçek olayların haberini yaparken sıklıkla olayları abartmakla suçlanmaktadır (Nordkvist Öman 2016). Buna örnek olarak, 2006'da Türkiye'de kuş gribinin neden olduğu turist sayısındaki düşüş̧e (Göçen vd. 2011), medya sürekli olarak olayı olduğundan daha kötü göstererek panik yaratmakla suçlanmıştır (turizmdebusabah, 2016). Dahası, medya ilgisinin azalması kesin olarak krizin aşıldığını da göstermez. "İlgi döngüsü" modelinin "kamu ilgisinin azalması" aşamasında, kriz tam olarak bertaraf edilmemekle birlikte kamuoyunun ilgi odağından düşer (Downs 1972; Hall 2002). Ayrıca, kitlesel medyanın inandırıcılığının azalması sonucu, sosyal medya karar alma sürecinde artan bir öneme kavuşmuştur (Procopio ve Procopio 2007). Öte yandan hedef bölgeler, kriz sonrası dönemlerde, (tetikleyici unsurlar çözümlenmemiş olsa bile) algı yönetimine yönelerek medyada tanıtım yoluyla zarar gören imajlarını düzeltmeye girişmektedirler (Ritchie 2004).

\subsection{Kriz Dönemlerinde Turistik Tüketici Davranışları}

Krizlerin ve ilgili risklerin turist akımlarını aksatmasının temel nedeni turizmin gerçek özneleri olan turistlerin davranışlarında yatmaktadır. Turizm talebi büyük oranda esnek, dönemsel ve dengesiz olabilir (Olalı ve Timur 1988; Kozak vd. 2015). Turistik satın alma karar alma sürecinde gerçek risk yerine turistin risk algısı daha belirleyici olmaktadır. Ayrıca yukarıda belirtildiği gibi bu algı medya, sosyal medya ve ağızdan ağıza iletişim (wom) gibi farklı kaynaklardan etkilenir.

İlk olarak, turistik satın alma kararı içseldir ve kaçınılmaz olarak belli oranda risk içerir. Satın alınan ve büyük oranda soyut olan turistik ürün (deneyim) tüketicinin evinden uzaktadır ve daha önceden deneme olanağı yoktur (Seabra vd. 2014). Dolayısıyla satın alma süreci, içsel olarak parasal ve psikolojik risk (doyumsuzluk) barındırır (Sönmez ve Graefe, 1996) ve tüketici doğal olarak bu riskten kaçınma eğilimindedir. Karşıt görüş olarak, Plog'un (1974)önerdiği dış merkezli (allo- 
Yıldız, Ö., Işıldar, P. / Journal of Yasar University, 2020, 15/59, 407-425

centric) turistler, genel turist pazarının küçük bir bölümünü oluşturmakla birlikte, değişen oranda heyecan ve macera aramaktadır. Ancak unutmamak gerekir ki, satın alma süreci belirli oranda bir parasal risk ve heyecan arayışı içermekle birlikte, can ve mal güvenliği risklerini içermez (Cater 2006).

Yüksek risk yanında yüksek katılım gerektiren bir süreç olan turistik satın alma kararı (Maser ve Weiermair 1998), büyük oranda kişisel tercih ve zevkler gibi irrasyonel unsurlardan etkilenir (Olalı ve Timur 1988). Karar alma süreci, bilgi ya da algıyı da hammadde olarak içermekte (Maser ve Weiermair 1998)ve risk de süreç içinde olası bir maliyet olarak değerlendirilmektedir (Sönmez ve Graefe 1998). Can ve mal güvenliği kaygıları, satın alma sürecinin son aşamalarında "engelleyici" işlevi görmektedir (Um ve Crompton 1990)ve turist belirsizlik ve riski azaltmak için daha fazla bilgi aramaktadır (Wahab vd. 1976). Bu durum iptaller, hedef bölge ya da ulaşım değişikliğine neden olabileceği gibi (Kozak vd. 2007), turist çözümlenmeyen riski kabul ederek planını değiştirmeme yoluna da gidebilmektedir (Hajibaba vd. 2015).

Turistlerin çoğunluğu, mantıklı olarak can ve mal güvenliği risklerinden kaçınmaktadır ve bu durumlarda planlarını değiştirmektedir. İş seyahatine çıkanlar her zaman bu kadar esnek olmayabilirler (Sönmez ve Graefe 1998). Ayrıca, belirgin risklere karşın seyahat planlarını değiştirmeyen turistlerle ilgili dikkate değer araştırmalar da bulunmaktadır. Hajibaba vd. (2015), bunları "krize dayanıklı turistler" olarak adlandırmıştır. Kozak vd. (2007) ise konuyu belirsizlikten kaçma ve riske dayanıksızlık ekseninde değerlendirmiştir. Henderson (2007) da turizm krizleri nedeniyle oluşan indirimleri firsat olarak değerlendiren turistlere dikkat çekmiştir. Ancak şimdiye kadar böyle bir pazar diliminin demografik özellikleri ile ilgili kesinleşmiş bir kanıt, ya da bu turistlerin ticari bir anlam taşıdı̆̆ına yönelik bir ortak kanı bulunmamaktadır.

Savaş, özellikle iç savaş durumlarında, sığınmacı/göçmen varlığı da, sürmekte olan krizi derinleştiren ek bir unsur olarak boy gösterir. Hedef bölgelerin içinde, özellikle turistlerin görüş alanlarında kamp yapmış sığınmacıların görüntüsü ek riskler yaratır. Dahası bu durum yalnızca bir güvenlik sorunu değil, ahlaki bir sorun da yaratır. Alışıldık turist gerçek hayattan kaçış ve rahatlama ararken, sığınmacı kampı görüntüsü gerçek hayatın acı bir yanını yansıtır (Nordkvist Öman 2016).

Sığınmacı krizlerinde, planları değiştirmek ya da değiştirmemek, iptal, ya da hedef bölgenin etkilenmemiş yerlerine gitmek gibi seçeneklerin yanında, turistler sığınmacılara yardım için kamp alanlarına gitmeyi de tercih edebilir. Bu kapsamda, 2015’te Norveç seyahat acenteleri, sığınmacılar için yardım içerdiği sürece yolculara ek bagaj hakkı tanıdı. Bunu tercih eden turistler, genel olarak öğretici ve kendini gerçekleştirici bir deneyim yaşadıklarını söylediler. 2015 sığınmacı krizi sırasında Yunanistan ve Türkiye'ye seyahat eden turistler üzerinde yapılan bir araştırma ayrıca değişen bir algıya işaret etmektedir; çok sayıda katılımcı durumun vahametini ancak kişisel olarak tanık olduktan sonra anladığını ifade etmiş̧ir. Bunun sonucunda seyahat planlarının hedef bölgeye vardıktan sonra değiştiği de görülmüştür (Nordkvist Öman 2016). Bu olay gönüllü ve sorumlu turizm kapsamında değerlendirilebilir.

\subsection{Kriz Yönetimi}

Turizm krizi, tanım olarak beklenmedik ve kontrol dışı olaylardan doğsa da, kaos ve değişim yönetimi turizm işletmeciliğinin önemli unsurudur; işletmeler ve hedef bölgeler bu gibi durumları süreç içerisinde olağan karşılamalı ve değişen koşullara uyum sağlayabilmelidir (Küçükaltan vd. 2015). Turizmin küresel özelliği, dinamik ve duyarlı yapısı göz önüne alındığında turizmde kriz yönetiminin önemi anlaşılmaktadır.

Turizmde kriz yönetiminin ilk aşaması krizin tanımlanması olacaktır (Parsons 1996).Tanımlama ölçütlerinden olan krizin içsel ya da dışsal kaynaklı oluşu, doğal ya da insan eliyle oluşması, tetikleyici olayların şiddeti, süresi ve etkilediği coğrafi alan gibi ölçütlere yukarıda değinilmiştir.

Kriz yönetiminde zamanlama yaşamsal öneme sahiptir. Zaman baskısı, kontrol düzeyi ve krizin şiddetine göre, yöneticiler farklı stratejileri benimseyebilirler:

a) Acil krizler: Uyarı vermeden krize neden olan tetikleyici olaylar, işletme ve hedef bölgelere araştırma, hazırlanma ya da planlama için süre tanımazlar.

b) Oluşan krizler: Yavaşça gelişen ve krize dönüşmekte olan olaylar, uyarıları izleyen işletmeler için krizi önleme firsatı sunar.

c) Süreğen krizler: Krize dönüşen ve uzun süredir devam eden olaylar (Parsons 1996).

Benzer biçimde Burnett (1998), krizleri zaman baskısı, kontrol düzeyi, tehlike düzeyi ve müdahale olanaklarına göre sıralamış, yoğun zaman baskısı ve tehlike, düşük kontrol ve müdahale olanağı özelliklerini taşıyan krizleri en ciddi krizler olarak sınıflandırmıştır. Krizin yaşam döngüsünü ise, Faulkner (2001) "olay öncesi”, "öncül/haberci”, "acil”, "kısa-orta dönem”, “uzun dönem (toparlanma)” ve “çözüm” olarak sınıflandırmıştır.

Ancak unutulmamalıdır ki, krizin içsel özelliğinden dolayı etkilerini önceden kestirmek ve uygun önlemleri almak bu kadar basit olmaz. Tetikleyici olay ya da olayların kendine özgü karmaşı özellikleri, medya ilgisi ve turist pazarlarının tepkileri gibi unsurlar her krize kendine özgü, kaotik ve karmaşık bir yapı kazandırır. Dahası, bir kriz diğer krizleri tetikleyerek bir "dalgalanma etkisi” de yaratabilir (Heath 1998). Bu da, her krizin kendine özgü bir yaklaşım, kimi durumlarda yan krizlerin önlenmesi gerektiği anlamına gelir. Krizin kaçınılmaz ve yönetimin doğal sürecinin bir parçası 
Yıldız, Ö., Işı1dar, P. / Journal of Yasar University, 2020, 15/59, 407-425

olduğu kabullenilmeli, yöneticiler değişime uyum sağlayacak biçimde krizlere etkin, stratejik ve pro-aktif yaklaşımlar geliştirmelidir (Ritchie 2004).

Bu yaklaşımla hazırlanan bir turizmde kriz yönetimi modeli şu şekildedir (Ritchie 2004):

a) Kriz önleme/planlama:

Tetikleyici olay öncesi ya da habercisi aşamalarında yöneticiler, olası ise krizi önlemeye ya da etkilerini öngörmeye yönelik çalışmalarda bulunur. Bu süreçte çevresel unsurlar, olaylar ve risk analizi yapılır, pro-aktif stratejiler belirlenir. Ardından acil duruma uygun eylem planı belirlenir (ve uygulanır).

b) Stratejik uygulama:

Acil ve kısa/orta erimde, strateji seçenekleri değerlendirilerek uygun olanı hızla uygulamaya koyulur. Bu aşamada kriz üzerindeki denetim düzeyi belirlenir. Özellikle uygun halkla ilişkiler iletişimiyle kriz kontrol altına alınmaya çalışılır. Kaynaklar belirlenir ve paydaşlar ile işbirliğine gidilir.

c) Çözüm, değerlendirme ve geribildirim:

Krizin son aşamalarında, toparlanmaya ve kriz öncesi duruma dönmeye yönelik çalışmalar yapılır. Kriz bir değişim aracı olarak kabul edilerek yeniden yapılanma için kaynak dağıtımı stratejileri belirlenir. Kriz yönetiminin etkinliği değerlendirilerek bir sonraki krizin daha iyi önlenmesi/yönetilmesi için öğretici çıkarımlarda bulunulur (Ritchie 2004).

Özellikle kriz sonrası aşamada, güvenlik tehdidi oluşturan etkenlerin ortadan kalktığı, güvenlik önlemlerinin artırıldığı, bölgenin yeniden güvenli olduğu ve her şeyin kriz öncesi duruma döndüğüne yönelik etkin bir iletişim, turist pazarlarının yeniden güveninin sağlanması ve bozulan imajın düzeltilmesi için yaşamsal öneme sahip olmaktadır. Çekim merkezlerinin güvenliğinin artırılmasına ek olarak, hassas bölgeleri ziyaret edecek kişilerin bilgilendirilmesi ve eğitilmesi de gerekli olabilir (Henderson 2007).

\section{Yöntem}

Çalışmada, 2016 krizinin çok boyutlu ve uzun erimli analizi için, öncelikle turizm krizleri ile ilgili alan yazını ve benzer örnekler incelenmiştir. Turizm krizlerinin yapısı, tetikleyici unsurları, turizm pazarlarının bunlara tepkileri, krizlerin yayılma ve süresi gibi özellikler üzerinde durulmuştur. Ardından, 2016 krizine neden olan tetikleyici olaylar, kronolojik olarak verilmiş ve bunların etkileri farklı dönemler ve turizm verileri üzerinde gösterilmiştir. Krizin olabildiğince uzun erimde ele alınabilmesi adına, TC Kültür ve Turizm Bakanlığı, TÜIK ve UNWTO'nun yayınladığı 2010 - 2018 arası resmi veriler kullanılmıştır. Olabildiğince çeşitli istatistiksel veri, uygun durumlarda birbiri ile ve / veya dünya geneli ile kıyaslanarak verilmiş ve yorumlanmıştır. Tetikleyici unsurların ve sonuçlarının yorumlanmasında, her ne kadar istenmeyen olaylar olsa da, olabildiğince nesnel bir dil kullanımına özen gösterilmiştir.

\subsection{Krizinin Tetikleyici Unsurlart}

Tablo 1'e geri dönüldüğünde, uluslararası turist girişlerinde belirgin düşüş 2016'da yaşanmakla birlikte, önceki yıllarda artış oranında bir düşüş yaşandığı, turizm gelirindeki düşüşün ise 2014'te başladığı görülmektedir. Turizm krizini 2016'da yaşanan yalıtılmış bir olay olarak değerlendirmek bu nedenle yanlış olacaktır. Aşağıda, krizin oluşumuna zemin hazırlayan tetikleyici olaylar incelenmiştir.

\subsubsection{Suriye İç Savaşı ve Sığınmacılar}

2010 yılı sonunda Tunus'ta başlayan ayaklanma ve iç karışıklık 2011 yılı başında Libya, Mısır, Suriye, Bahreyn ve Yemen'e yayılmıştır. "Arap Baharı” olarak adlandırılan olaylarda, bu ülkelerin yönetimleri ve toprak bütünlüklerinde önemli değişimler yaşanmıştır (BBC News Türkçe 2017a). 15 Mart 2011'de başlayan (ve halen süren) Suriye iç savaşında günümüze kadar yarım milyon insanın yaşamını kaybettiği, üç milyon kişinin de yaralandı̆̆ı, 23 milyon nüfuslu Suriye'de 11 milyon kişinin yerinden edildiği, 5,4 milyon kişinin ise sığınmacı olduğu tahmin edilmektedir (DW 2018b). Türkiye yaklaşık 3,5 milyon sığınmacıyı ağırlamaktadır (Ağır 2017). Buna ek olarak, Ege üzerinden Avrupa ülkelerine sığınmak isteyen çok sayıda göçmenin, (Bodrum ve Marmaris gibi) yabancı turistlerin yoğun olarak ziyaret ettiği liman bölgelerinde kamp kurması, güvensiz yollarla yolculuğa çıkması ve yaşamlarını kaybetmesi gibi üzücü olaylar yaşanmıştır (Gümüş 2015;Nordkvist Öman 2016). Türkiye'de yaşayan Suriyeli sı̆̆ınmacıların güvenlik sorunlarına neden olduğu, (sosyal) medyada sıklıkla dile getirilmektedir. Sonuçta komşu ülkede yaşanan iç savaş, istikrarsızlık ve güvenlik tehdidinin yayılması, turistler üzerinde psikolojik baskı ve ülkede güvensizlik algısı oluşmasına neden olmuştur. Bölgede oluşan istikrarsızlık, Hırvatistan örneğinde de olduğu gibi bir genelleme etkisi yaratarak Türkiye'nin imajını da etkilemiştir. 
Yıldız, Ö., Işıldar, P. / Journal of Yasar University, 2020, 15/59, 407-425

\subsubsection{Rus Savaş Uçağının Düşürülmesi}

Arap Baharı, Suriye iç savaşı ve bağlantılı IŞiD / DAEŞ saldırıları ile sürece Rusya müdahil olmuştur. 31 Ekim 2015’te Mısır'dan kalkan sivil Rus uçağı terör saldırısı sonucu düşürülerek 224 yolcu ve mürettebat yaşamını yitirmiştir (BBC News Türkçe 2015). 24 Kasım 2015'te Suriye'nin kuzeyinde manevra yapan bir Rus savaş uçağı, Türk hava sahasını ihlal ederek düşürülmüştür. Rusya yönetimi vatandaşlarına Mısır ve Türkiye için yolculuk kısıtlaması getirmiştir. Uzun süren resmi görüşmeler sonucu 2016 Eylül başında Rusya'dan Türkiye'ye charter uçuşlar yeniden başlayarak kısıtlama kaldırılmışırı. Ancak bu durum, Türkiye'ye 2016 yılının (mevsimsel yoğunluğun yaşandığı yaz ayının neredeyse tamamını da kapsayan) ilk sekiz ayı boyunca neredeyse hiç Rus turist gelmemesine neden olmuştur(Karabulut 2017). Yine de, bu düşüşün yalnızca Türkiye (ve Mısır) ile ilgili olmadığı, Rusya'nın, ülke ekonomisi ile ilgili nedenlerden dolayı 2016'da dış pasif turizmde önemli bir düşüş yaşadığı da eklenmelidir. Rusya'nın 2012'de 48, 2013'te de 59,5 milyar Amerikan dolarına ulaşan uluslararası turizm harcaması, 2014'te 55,4, 2015'te 38,4, 2016'da ise 27,6 milyar Amerikan dolarına gerilemiştir (OECD, 2018).

\subsubsection{Terör Olayları}

2015 ve 2016 yılları, Türkiye’de terör olaylarının yoğun olarak yaşandığı bir dönem olmuştur. PKK ve bağlantılı örgütlere ek olarak, IŞiD/DAEŞ ve bağlantılı örgütler, turistlerin de doğrudan etkilendiği ve çok sayıda yaşam kaybına neden olan saldırılar gerçekleştirmiştir. Yalnızca 2016'da, Türkiye'de 336 kişinin yaşamını yitirdiği, 1500'den çok kişinin de yaralandığ 27 terör eylemi kayıtlara geçmiştir.

10.09.2015: Ankara Garı önünde düzenlenen mitinge gerçekleştirilen DAEŞ saldırısında 103 kişi yaşamını yitirdi, 391 kişi yaralandl. Türkiye tarihinin en kanlı intihar saldırısinda yakalanan 9 sanık "anayasal düzeni değiştirmeye teşebbüs" ve "kasten öldürme" suçlarından toplam 101'er kez ağırlaş̧tırlmış müebbet hapis cezası verildi (Öksüz ve Batu 2017; BBC News Türkçe 2018; CNN Türk 2018).

12.01.2016: İstanbul Sultanahmet Meydanı'nda IŞSiD/DAEŞ'in gerçekleştirdiği canlı bomba saldırısı sonucu içinde 11'i Alman turist olan toplam 12 kişi yaşamını yitirdi, 16 kişi de yaralandı. 3 sanığa ağırlaştırılmış müebbet hapis ile 329'ar yul hapis cezast verildi. Istanbul'un en önemli çekim merkezinde gerçekleşen ve Alman turistlerin doğrudan etkilendiği saldırı uluslararası basında geniş yer buldu ve Almanya hükümeti resmi yolculuk uyarısında bulundu ve bazı Alman seyahat aracıları Türkiye turlarını iptal etti (Varlı 2016; Öksüz ve Batu 2017).

17.02.2016: Ankara Çankaya'da Merasim Sokak'ta PKK üyelerinin gerçekleştirdiği saldırıda 29 kişi yaşamını yitirdi, 61 kişi yaralandı. 6 sanığa "devletin birliğini bozmak" ve 29 kişiyi öldürmekten 30'ar kez ağırlaştırılmış ömür boyu hapis cezası verildi (Öksüz ve Batu 2017; Hürriyet 2018).

13.03.2016: Ankara Kızllay'da PKK üyeleri tarafinda bomba yüklü araç ile, çevik kuvvet polislerini hedef alan ancak otobüs durağında gerçekleşen saldırıda 37 kişi yaşamını yitirdi ve 125 kişi yaralandı. Başkentte yoğunlaşan terör eylemleri halkta önemli bir tepkiye neden oldu (Hürriyet 2016a). PKK bomba yüklü araç ile 10 ve 12 Mayls'ta Diyarbakur'da, 7 Haziran'da İstanbul Vezneciler'de, 8 Haziran'da Mardin'de, 1

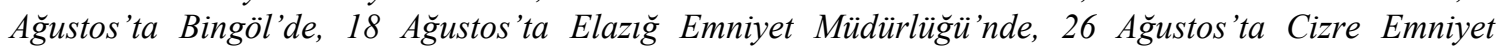
Müdürlügü̈nde, 6 Ekim'de İstanbul Yenibosna'da, 9 Ekim'de Şemdinli Jandarma Karakolu'nda, 24 Kasım'da Adana Valiliği'nde, 10 Aralık'ta İstanbul Beşiktaş'ta ve 17 Aralık'ta Kayseri'de saldirllarda bulunmuş̧tur. Beşiktaş'ta gerçekleşen saldırıda 44 kişi yaşamını yitirmiş, 155 kişi yaralanmıştır (Öksüz ve Batu 2017).

28.06.2016: İstanbul Atatürk Havalimanı dış hatlar terminalinde IŞID/DAEŞ’in gerçekleştirdiği silahlı canlı bomba saldırısında içinde polis, havalimanı çalışanı ve uluslararası turistlerin de bulunduğu 43 kişi yaşamını yitirdi, 239 kişi yaraland. Türkiye'nin en önemli uluslararası havalimanının ve turistlerin doğrudan etkilendiği saldırı sonrası havalimanı kapatıldı ve uçuşlar iptal edildi (Hürriyet 2016b).

04.11.2016: TAK ve IŞSiD/DAEŞ, Diyarbakır Il Emniyet Müdürlü̈̆̈̈'ne ait Terörle Mücadele ve Çevik Kuvvet Şube Müdürlügü’ne bomba yüklü araç ile saldırl düzenledi. 2'si polis, 1 teknisyen, 8 sivil olmak üzere 12 kişi yaşamını yitirdi, 100'e yakın kişi yaralandı (Öksüz ve Batu 2017).

Topluca değerlendirildiğinde, terör olaylarının özellikle Ankara ve İstanbul'da, ayrıca uluslararası turistlerin yoğun olarak bulunduğu yerlerde gerçekleşmiş olması, hem uluslararası basında geniş yer bulmasına hem de ülkenin turist pazarlarındaki imajının ve güven algısının yitirilmesine neden olmuştur. Saldırıların 2016'da sürekli hal alması da "dalgalanma etkisi" yaratarak krizi derinleştirmiştir. Olayları izleyen resmi seyahat uyarıları ile tur ve rezervasyon iptalleri turistik işletmeler için durumun daha da kötüleşmesine neden olmuştur. 
Yıldız, Ö., Işı1dar, P. / Journal of Yasar University, 2020, 15/59, 407-425

\subsubsection{Temmuz 2016 Darbe Girişimi}

15 Temmuz akşamı, daha sonra FETÖ terör örgütü üyesi oldukları açıklanan bir grup asker darbe girişiminde bulunmuştur. 16 Temmuz'a bağlayan gece halk ile darbeci askerler karşı karşıya gelmiştir. Girişim başarısız olmakla birlikte, 104'ü asker 300 'den çok kişi yaşamını yitirmiş, 1500 kişi yaralanmıştır. Havaalanları trafiğe kapatılmıs, çok sayıda askeri ve kamu çalışanı gözaltına ve/veya soruşturmaya alınmıştır. 21 Temmuz'da olağanüstü hal (OHAL) ilan edilmiş ve 2 yıl sürmüştür. Kamu çalışanlarının yıllık izinleri iptal edilmiş ve izinde olanlar göreve çağrılmıştır. Yurtdışı çıkışlarına kısıtlama getirilmiştir. Bu süreçte belirli ülkelerle dış ilişkilerde gerilim yaşanmıştır (Haber Turk 2016).

\subsubsection{Seyahat Uyarıları}

Bu süreçte pek çok turist gönderen ülkenin hükümetleri Türkiye'ye yönelik yolculuklar konusunda vatandaşlarına uyarılar ve kısıtlamalar getirmiştir (Rusya'nın getirdiği kısıtlamadan yukarıda bahsedilmiştir). 2013'te, Gezi olayları sonrasında ABD, Almanya, İngiltere ve İtalya gibi ülkelerin Türkiye'de bulunan ve seyahat edecek vatandaşlarına yaptıkları uyarıları da burada anımsatmak gerekli olacaktır (Turizm Gazetesi 2013).

ABD, Mart ve Haziran 2016'da terör tehdidi nedeniyle vatandaşlarına seyahat uyarısı yayınlamış ve Suriye sınırına yakın yerlere seyahat etmemeleri konusunda uyarmıştır (Cumhuriyet 2016a). 15 Temmuz darbe girişiminin ardından OHAL ve büyükşehirlerde yaşanan terör eylemlerini işaret ederek Temmuz ve Ağustos'ta Türkiye'ye seyahat uyarısı yayınlamıştır. 16 Güneydoğu iline yolculuk yasağı getirmiştir (BODER 2016). Türkiye'de görev yapan ABD askeri ve diplomatik personeline tahliye / gönüllü geri dönüş kararı vermiştir. 2017 sonu ve 2018 başında seyahat uyarılarını yineleyen ABD, Türkiye'yi en riskli ülkeler arasında ilan etmiştir (Sözcü 2016). Darbe girişimi ve seyahat uyarıları sonucu iki ülke arasındaki ilişkiler gerilmiştir. 5 Eylül 2019'da, ABD Dışişleri Bakanlığı, Suriye sınırındaki bölgelerin en riskli (4. seviye), Güneydoğu illerinin riskli (3. seviye) durumunun devamını duyururken, ülke geneli için uyarı durumunu yumuşatarak düşük riskli (2. seviye) ilan etmiştir (VOA 2018; US Department of State 2019).

Almanya, 12 Ocak Sultanahmet, 13 Mart Ankara, 7 Haziran Vezneciler, 24 Kasım Adana ve 10 Aralık Beşiktaş saldırıları ile 15 Temmuz darbe girişimi ardından vatandaşlarını politik gerilim, çatışma ve terör nedenleriyle uyararak büyükşehirler ve kalabalık yerlerden kaçınmalarını önermiştir (BBC News Türkçe 2016; Yeni Hayat 2016; Yolculuk 2016). Eylül 2017, Ekim 2018 ve Ocak 2019’da üç uyarı daha yapılmıştır (REFTUR 2016; DW 2018a).

Birleşik Krallık, Nisan 2016'da Suriye sınırı için terör tehdidi gerekçesiyle seyahat uyarısı yayınlamış, uyarıyı Ocak 2018'de yinelemiştir (Sarı 2018). İsviçre, 2016 ve 2017 'de, OHAL nedeniyle vatandaşlarını giriş işlemleri ve tutuklamalar konusunda uyarmıştır (CNN Türk 2017). Kanada, 2016'nın ilk aylarında terör eylemleri nedeniyle vatandaşlarını Türkiye’ye yapılacak zorunlu olmayan seyahatlere karşı uyarmıştır. Ağustos’ta resmi uyarıyı kaldırmakla birlikte, vatandaşlarını azami dikkat gösterme ve Suriye sınırına yakın bölgelere seyahat etmeme konusunda uyarmışırır (Cumhuriyet 2016b). Hollanda ile 2017'nin ilk aylarında yaşanan diplomatik kriz sonucu, bu ülke de seyahat uyarısında bulunmuş, ancak uyarıya Hollanda Seyahat Acenteleri Birliği tepki göstermiştir (BBC News Türkçe 2017b).

\subsection{Verileri}

Yukarıda incelenen Tablo 1 ve tetikleyici unsurlar ışığında, Türkiye turizminin 2010 - 2018 dönemi istatistiksel verileri aşağıda incelenerek krizin başlangıç, gelişim ve sonucu yorumlanacaktır. 2016 yıll, Türkiye turizm tarihinde uluslararası turist girişleri ve turizm gelirinde en ağır düşüşün yaşandığ 1 yll olmakla birlikte, krizin bir yıl içerisinde değerlendirilmesi yanıltıcı olacaktır. Tetikleyici unsurlar, 2011 Arap Baharı olaylarına kadar dayandırılabilir. Somut olarak, 2013 sonunda başlayan seyahat uyarıları, sığınmacı sorunu, ardından 2015 sonunda Rus savaş uçağının düşürülmesiyle başlayan diplomatik kriz ve seyahat engeli, 2016 boyunca süren terör olayları ve darbe girişimi, 2016'daki krizin temel nedenleri olmuştur.

Uluslararası turizm pazarında 2011 yılından beri uluslararası turist girişleri bakımından 6. olan Türkiye, 2016'da 10. sıraya gerilemiş, 2017 yılında 8. sıraya yükselmiş ve 2018 yılında da 6. sıraya geri dönmüştür. Yine 2011 yılından beri uluslararası turizm gelirinde 12. sirada olan Türkiye, 2016'da 17. sıraya kadar gerilemiş, 2017'de 14, 2018'de de 13 . siraya yükselmiştir (UNWTO 2019). 
Yıldız, Ö., Işıldar, P. / Journal of Yasar University, 2020, 15/59, 407-425

Tablo 3. Türkiye Uluslararası Turist Girişleri ve Turizm Geliri, 2010-2018

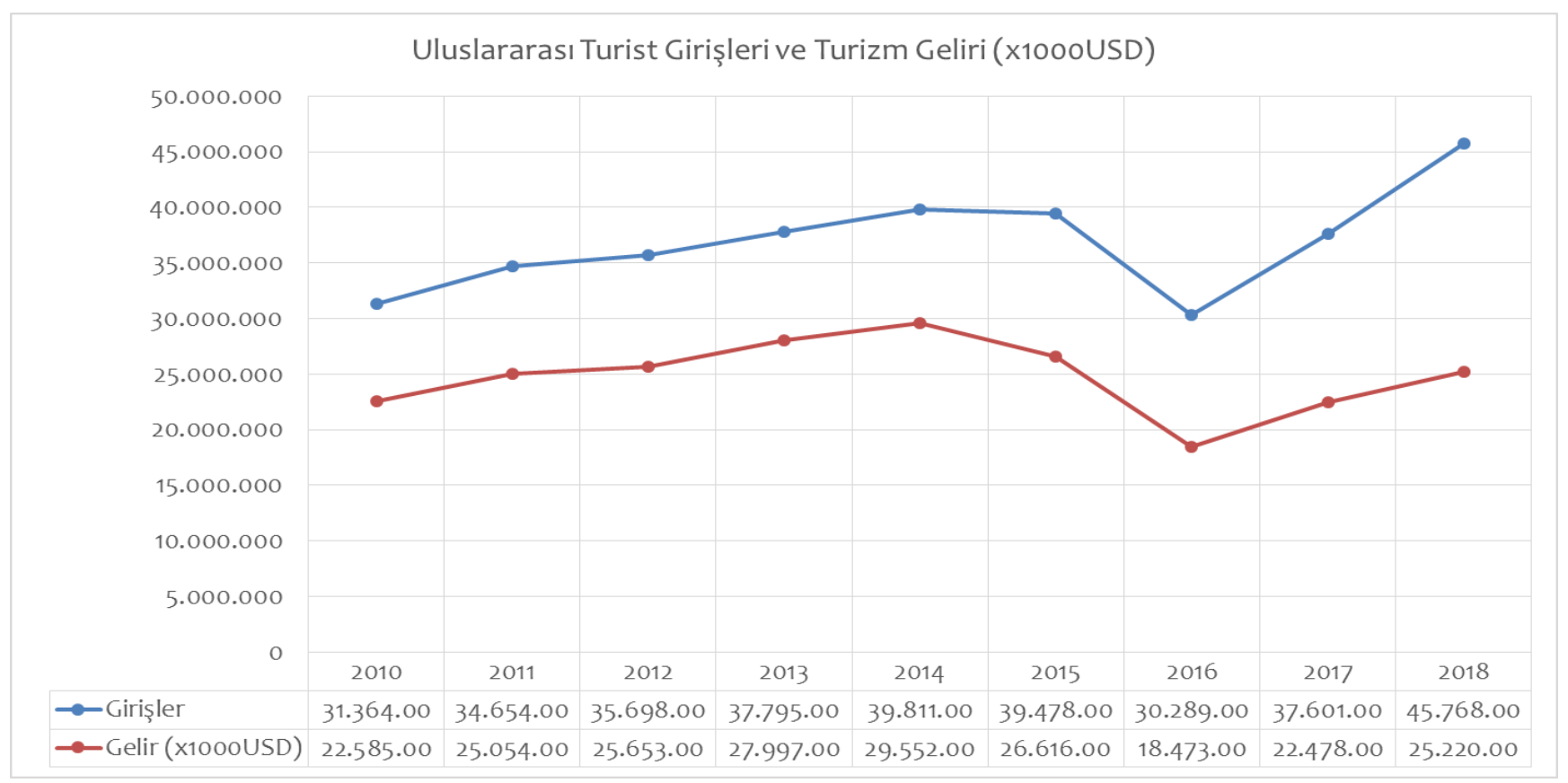

Kaynak:UNWTO, 2019

Birleşmiş Milletler Dünya Turizm Örgütü verilerine göre hazırlanmış olan Tablo 3 incelendiğinde, turist sayıları ve turizm gelirlerinin olarak 2014'ten sonra düşmeye başladığ 1 açıkça görülmektedir. 2017 ve 2018 yılları, turist sayıları ve turizm gelirlerinin önemli ölçüde arttığı, başarılı toparlanma yılları olarak görülmektedir; ancak turist sayısı bakımından krizin 2018 'de atlatıldığı, turizm geliri bakımından ise krizin halen atlatılamadığı görülmektedir.

Faulkner (2001) kriz yaşam döngüsü modeline göre, 2011-2014 arası "olay öncesi”, 2014 yılı "öncül/haberci”, 2015 ve 2016 “acil”, 2017 ve 2018 "kısa-orta dönem" olarak sınıflandırılabilir. Önümüzdeki yılların "uzun dönem (toparlanma)" ve "çözüm” olacağı öngörülebilir. Parsons (1996) modeline göre ise, kriz 2014 yılında "oluşmaya başlamış" görülmektedir. Bu dönemde kriz yavaşça gelişmekte ve tetikleyici unsurların izlenmesi gerekmektedir. Ülkenin ve turistik işletmelerin çok düşük kontrol sahibi olduğu dışsal olaylar önlenemediğinden kriz "süreğen" hal almış ve 2016'daki düşüş gerçekleşmiştir. Burnett (1998) sınıflandırmasına göre 2016, yoğun zaman baskısı ve tehlike, düşük kontrol ve müdahale olanağı özelliklerini taşıdığı için“en ciddi kriz" olarak sınıflandırmalıdır. Son olarak, Downs (1972) ilgi döngüsü modeline göre 2017 sonrası, terör olaylarının azalması ve Rusya diplomatik krizinin sona ermesiyle birlikte, (özellikle Hollanda, Almanya ve Birleşik Krallık gibi) önemli turist gönderen ülkelerin seyahat uyarılarının sürmesine rağmen, bu dönem "kamu ilgisinin azalması" aşaması olarak kabul edilebilir. 


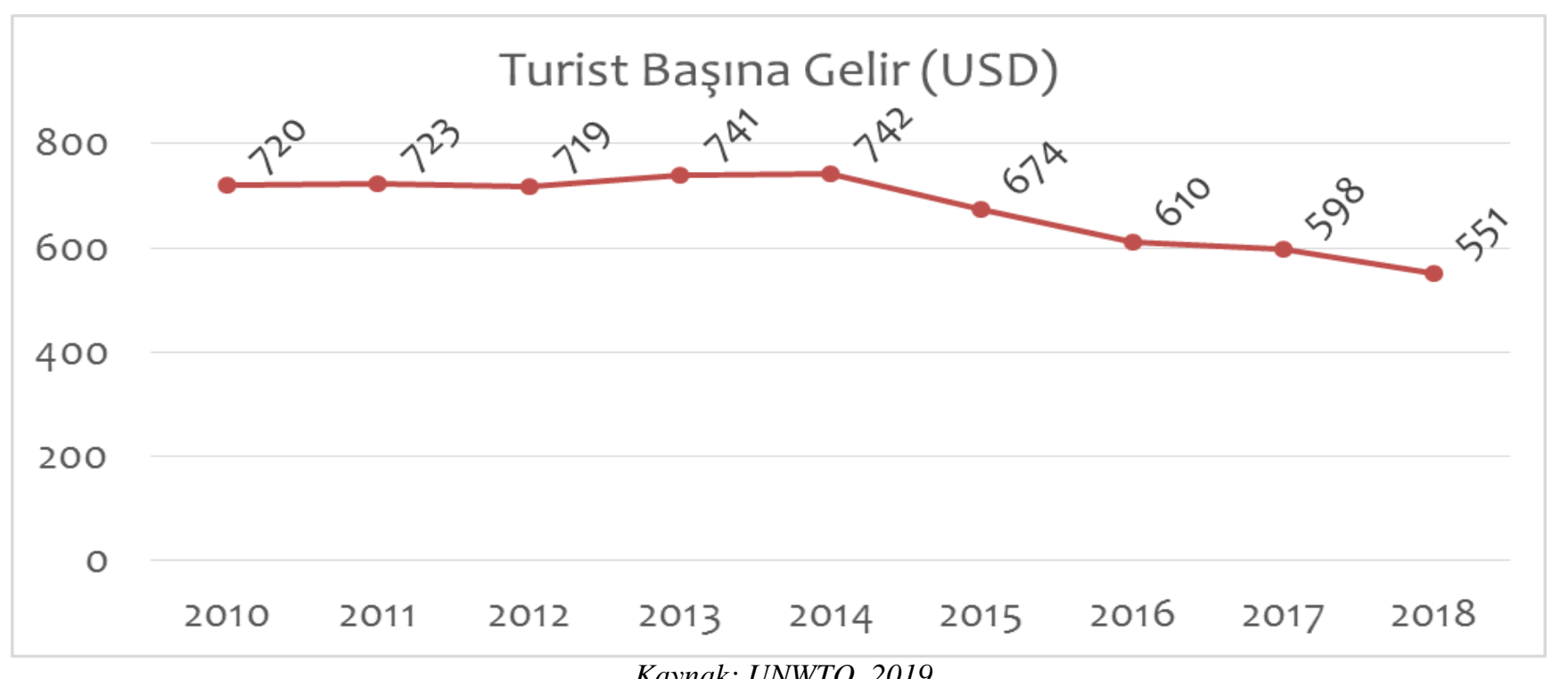

Kaynak: UNWTO, 2019

Türkiye’nin turist başına elde ettiği gelirin seyri incelendiğinde ise daha farklı bir görüntü çıkmaktadır. 2014 yılında duraklama başlamış, ardından sürekli bir düşüş yaşanmıştır. 2015 ve 2016 acil kriz dönemi kabul edildiğinde, turizm işletmeleri acil duruma tepki olarak fiyat indirimlerine gitmiş, bu da turist başına gelirde düşüşe yol açmış görünmektedir. Toparlanma sürecinde ise düşüş sürmüştür. Bunun oluşan pazar basklsı ile açılanması doğru olacaktır. Daha önce turist başına gelirin dünya ortalamasının 1000 Amerikan dolarının üstünde olduğu belirtilmişti. Bu krizle birlikte, Türkiye'nin turist başına elde ettiği gelir dünya ortalamasının yaklaşık yarısına kadar düşmüş görünmektedir.

Daha ayrıntılı ve geçerli çıkarımların alınması için Türkiye’nin turizm verilerini tek başına değerlendirmek yerine, Tablo 5’te gösterilen dünya turizminden aldığı payın incelenmesi daha doğru olacaktır.

Tablo 5. Türkiye’nin Toplam Uluslararası Turist Sayıları ve Turizm Gelirinden Aldığı Pay

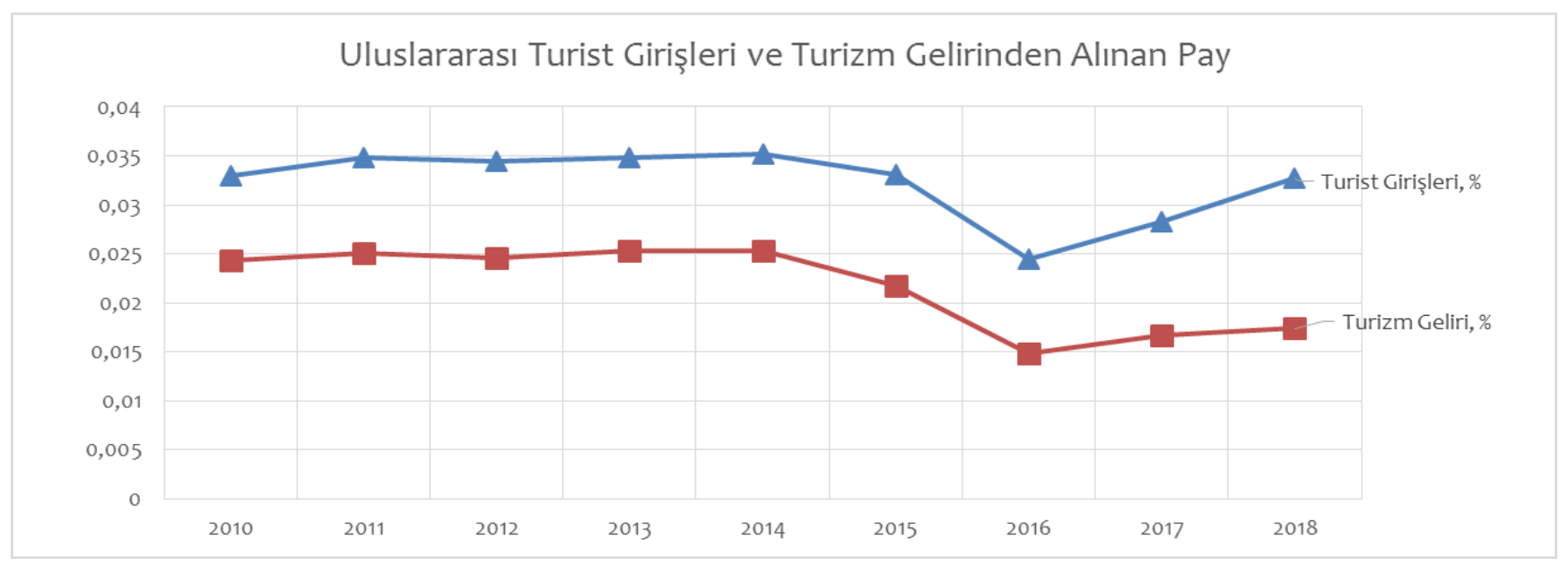

Kaynak: UNWTO, 2019

Yine Birleşmiş Milletler Dünya Turizm Örgütü verilerine göre hazırlanmış olan Tablo 5 incelendiğinde, Türkiye'nin turist sayıları ve turizm geliri bakımından dünya turizm pazarından aldığı payın halen 2014'ün gerisinde olduğu görülmektedir. Bu durum, krizin 2018 itibariyle halen atlatılamadığını göstermektedir.

Krizin ekonomik anlamda değerlendirilebilmesi için, 2016 turizm geliri, 2015 verileriyle klyaslanabilir. Türkiye, UNWTO (2019)verilerine göre, bir yıl içerisinde 8 Milyar Amerikan dolarından fazla gelir kaybı yaşamış görünmektedir. Oysaki turizm gelirleri 2011-2014 yılları arasında tam \%7 artış kaydetmekteydi. Bu gelişimin sürmesi durumunda, 2015 geliri 31,6 ve 2016 geliri 33,8 milyar Amerikan doları olacaktı. Bu varsayımla, 2014-2018 arasında Türkiye’nin toplam turizm geliri kaybı 47,6 milyar Amerikan doları olarak hesaplanmıştır. 
Analiz daha da derinleştirilmek istenirse, turistik gelirin çarpan katsayısı da dikkate alınmalıdır. Doğal olarak, Türkiye'nin uluslararası turizmden kazandığı gelir tek başına değerlendirilmemeli, ülke ekonomisi için yarattığı toplam gelir etkisi dikkate alınmalıdır. Önceki bir çalışmada (Timur 2014), çarpan katsayısı 5 devir dönemi için 3,743 olarak bulunmuştur. Bu katsayının doğruluğu varsayımında, nominal olarak 4 yıl içinde 47,6 milyar kaybettiği kabul edilen Türkiye’nin, gerçek anlamda 178 milyar Amerikan doları kaybı söz konusudur.

Tablo 6. Yıllara göre Turizm Yatırım Belgeli Konaklama Tesislerinin Sayısı [2010-2019 (ilk 8 ay)]

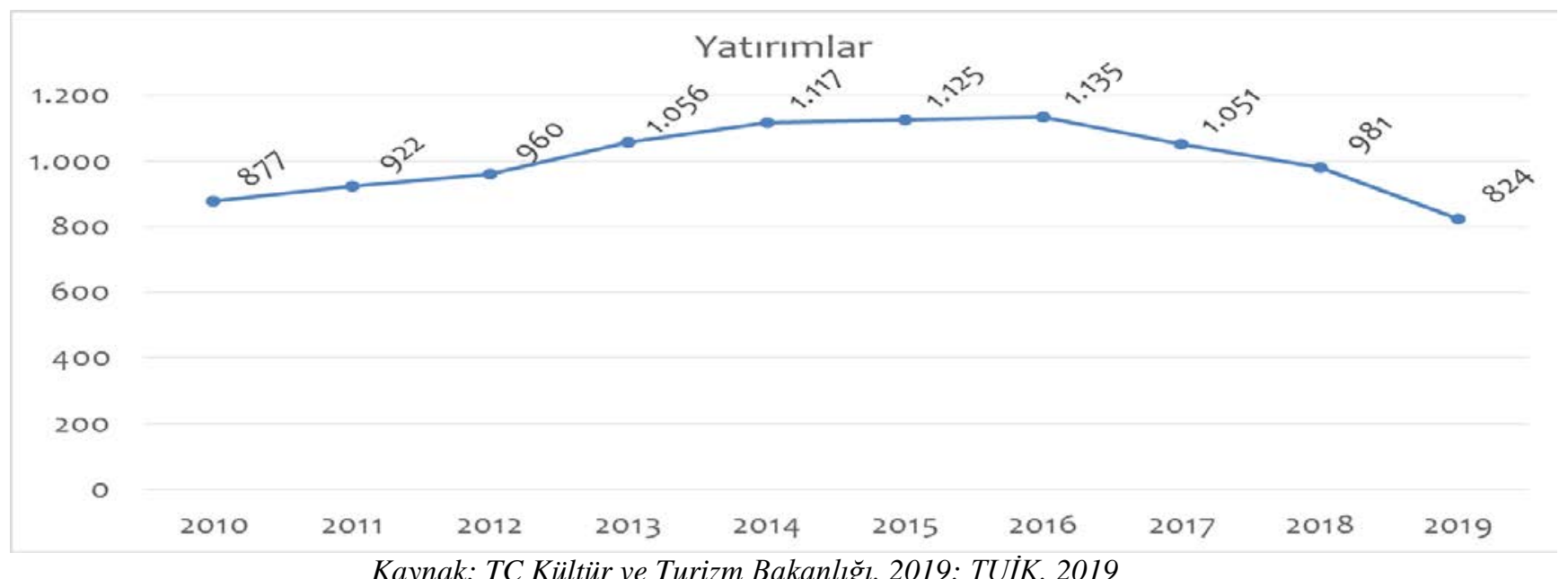

Kaynak: TC Kültür ve Turizm Bakanlığl, 2019; TUiK, 2019

2016'da yaşanan krizin, yatırımlara etkisinin incelenmesi için, T.C. Kültür ve Turizm Bakanlığı belgeli konaklama işletmesi yatırımlarının seyrine bakılabilir. 2010 yılından itibaren yatırımlar düzenli olarak artmış, 2014 yllından itibaren duraklamaya, 2016 yılından itibaren de düşmeye başlamıştır. Yatırım kararının alınması ile yatırıma geçilmesi arasındaki sürede, yatırımcılar oluşmakta olan krizi izlemiştir. Acil kriz döneminin ardından da, olası yatırımcıların yatırımdan vazgeçtikleri görülmektedir. Turistik yatıımların gelir ve çarpan etkileri de dikkate alındığında, son 2016-2018 arasında \%21 yatırım kaybının ülke ekonomisi için önemi anlaşılmaktadır.

Turist girişleri ve yatırımlardaki azalma, istihdam kaybı olarak da kendini göstermiştir. Yalnızca 2016 yaz aylarında, 2015'e göre otel işletmelerinde istihdam kaybı 60-70 bin çalışan arasında, yaklaşı \%20 olarak gerçekleşmiştir (Karabulut 2017). 
Yıldız, Ö., Işıldar, P. / Journal of Yasar University, 2020, 15/59, 407-425

Tablo 7. T.C. Dışsatım Miktarları, 2010-2018

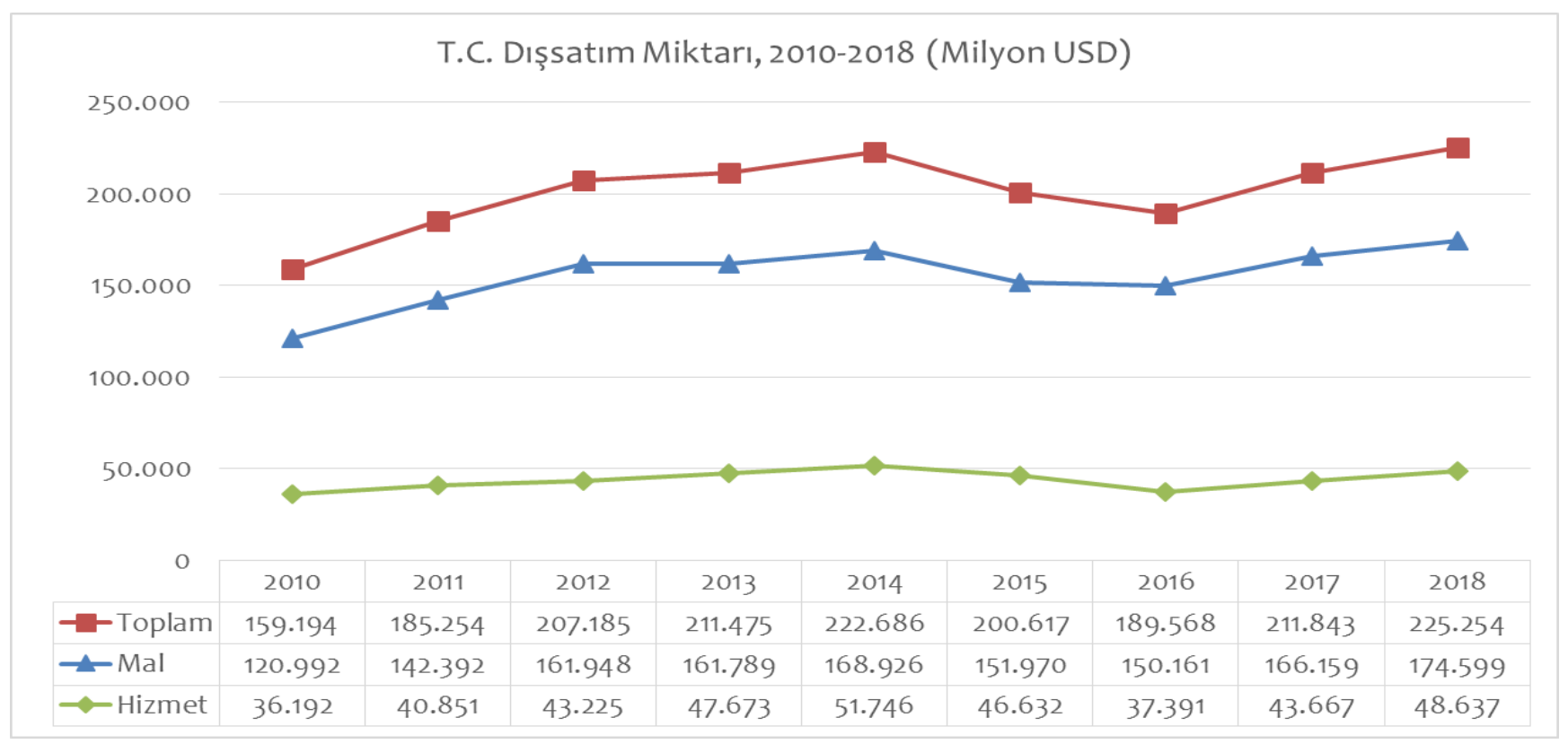

Kaynak: TCMB, 2019

Turizm gelir kaybının ulusal gelire etkisi incelenmek istendiğinde, Tablo 7'de verilen dışsatım miktarındaki yıllar içindeki değişime bakılabilir. Hem hizmet, hem de mal dışsatımında, 2014'te başlayan ve 2016'ya dek süren bir düşüş gözlenmektedir. Her ne kadar turizm Türkiye ekonomisi için önemli olsa da, bu gelir kaybını yalnızca turistik gelir kaybına bağlamak yanıltıcı olacaktır. Ancak unutulmamalıdır ki, turizm krizine neden olan tetikleyici olayların genel ülke ekonomisi için de olumsuz etkileri olmuştur.

Kriz tetikleyici unsurların ülke turizmi üzerindeki ayrıntılı sonuçları, aşağıdaki tablolar üzerinden incelenecektir. Yurtdışında yaşayan Türk vatandaşlar ve yabancı ziyaretçilerin sayıları Tablo 8'de verilmiştir:

Tablo 8. Türkiye’ye Gelen Yabancı, Türk ve Toplam Ziyaretçi Sayıları, 2010 - 2018

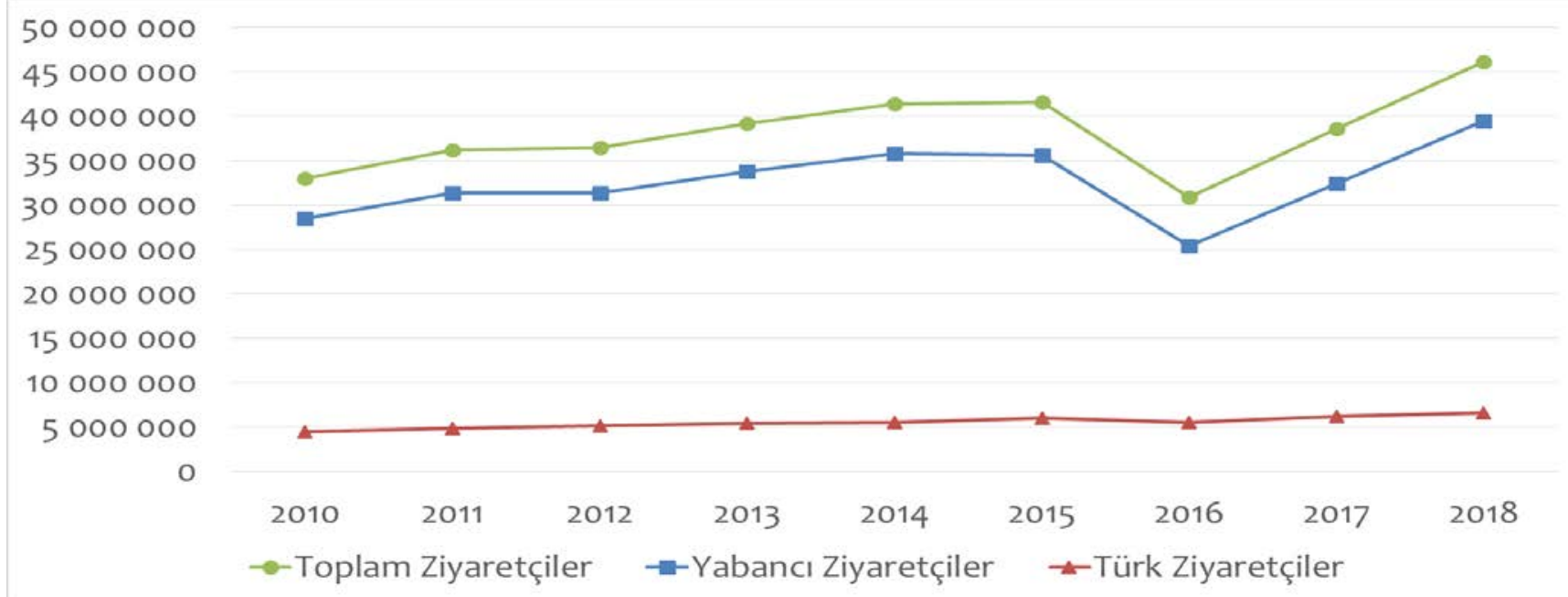

Kaynak: TC Kültür ve Turizm Bakanlığı 2019; TUiK 2019

Tablo 8 incelendiğinde kriz tetikleyici unsurlardan Türk vatandaşlarının neredeyse hiç etkilenmediği, önemli düşüşün yabancı ziyaretçi sayısında yaşandığı görülmektedir. Bu durumun ülkenin yabancı pazarlardaki imajı ve kriz tetikleyici unsurlar ile ilgili iletişimden dolayı olduğu öne sürülebilir. Daha ayrıntılı bir döküm, ziyaretçi sayılarının turist gönderen ülkelere göre dağılımın incelenmesiyle mümkün olacaktır: 
Yıldız, Ö., Işıldar, P. / Journal of Yasar University, 2020, 15/59, 407-425

Tablo 9. Türkiye’ye Gelen Yabancı Ziyaretçilerin Milliyetlerine göre Dă̆ı̆lımı (2010-2018)

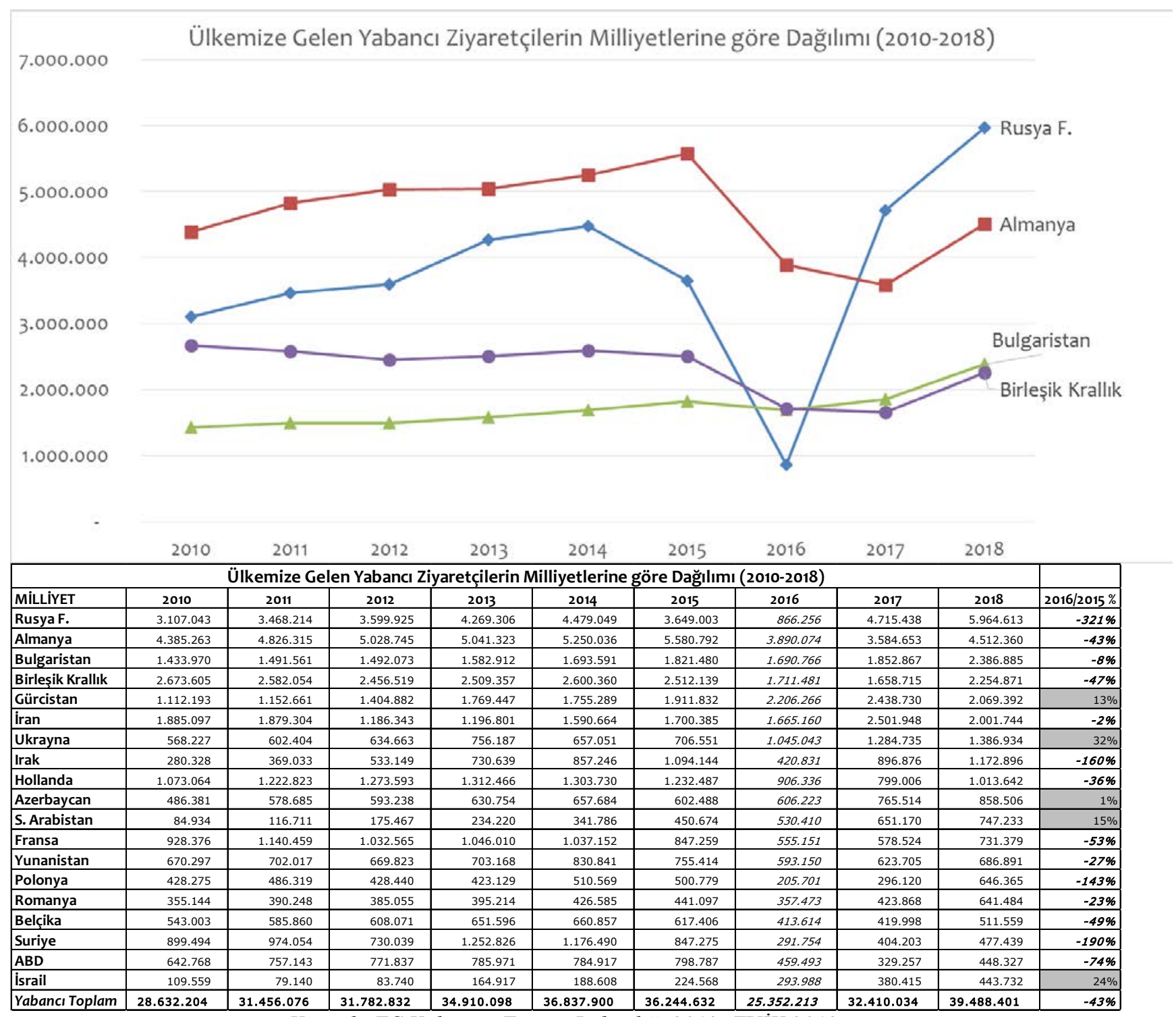

Kaynak: TC Kültür ve Turizm Bakanlı̆̆ 2019; TUIKK 2019

Tablo 9, Türkiye için en önemli turist gönderen ülkeleri göstermektedir. Rusya ile yaşanan kriz ve bunu izleyen seyahat yasağı sonucu yaşanan düşüş açık biçimde görülmektedir. Burada Rusya'dan yılın ilk sekiz ayı (neredeyse) hiç ziyaretçi gelmediğinin anımsatılması yerinde olacaktır. Ayrıca Rusya dış pasif turizminde yukarıda belirtilen düşüş sonucu, Rusya'dan gelen ziyaretçi sayısındaki düşüşün 2015 'te başladığı da görülmektedir. Sonuç olarak 2016 yılında ağırlanan Rus ziyaretçi sayısı, 2002 yılının altında kalmıştır. Yine 2016'da (bazıları resmi seyahat uyarısı da yayınlayan) Almanya, Birleşik Krallık, Hollanda, Fransa ve Belçika'dan gelen ziyaretçi sayısında, birbirine yakın düşüş oranları gözlenmiştir. Bu sonuçtan, bu ülke vatandaşlarının seyahat tercihlerinin ve / veya bilgi paylaşımının birbirine yakın olduğu öne sürülebilir. Ayrıca Almanya, Birleşik Krallık, Hollanda ve ABD'den gelen ziyaretçi sayılarındaki düşüş, bu ülkelerin yayınladıkları seyahat uyarıları ve ülkeler arası ilişkilerin zayıflaması nedenleriyle 2017 'de de düşmeyi sürdürmüştür. Anılan ülkelerden gelen ziyaretçi sayıları ancak 2018'de artmış, fakat yine de 2015'in altında kalmıştır. Irak ve Suriye'den gelen ziyaretçi sayısındaki dalgalanmalar bölgedeki savaş koşullarının yayılma etkisi ve bu ülkelerin kendi koşullarıyla açıklanmalıdır.

Genel düşüşe rağmen, Gürcistan, Ukrayna, Azerbaycan, Suudi Arabistan ve İsrail'den gelen ziyaretçi sayısında artış, Bulgaristan ve İran'dan gelen ziyaretçi sayısında ise ortalamanın çok altında, Yunanistan, Romanya ve (tabloda görünmeyen) Ermenistan'dan gelen ziyaretçi sayısında ise ortalamanın altında bir düşüş yaşanmıştır. Bu durum, alan yazınında görülen komşu (ve yakın bölge/kültür) ülkelerden girişlerin daha az etkilendiği önermesini desteklemektedir. Ukrayna'dan yaşanan ziyaretçi artı̧̧ı ayrıca Rusya boykotu ile de ilişkilendirilebilir. 
Yıldız, Ö., Işı1dar, P. / Journal of Yasar University, 2020, 15/59, 407-425

Tablo 10. Türkiye’ye Gelen Yabancı Ziyaretçilerin Aylara göre Dağılımı (2010-2018)

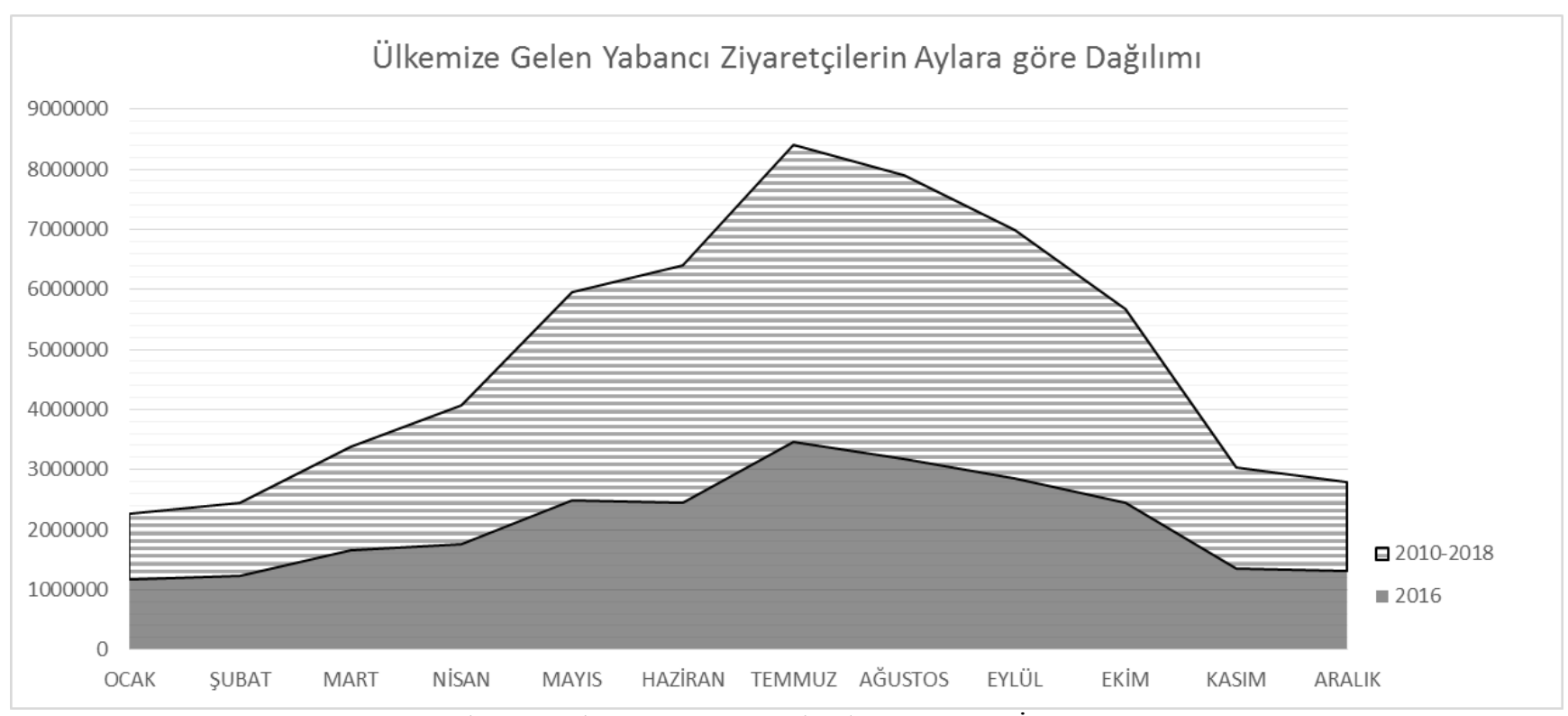

Kaynak: TC Kültür ve Turizm Bakanlı̆̆ı 2019; TUIK 2019

Tablo 10'da 2010-2018 arasında (2016 hariç tutulmuştur) Türkiye’ye gelen yabancı ziyaretçilerin aylara göre dağglımının ortalaması, 2016 verileriyle karşılaştırmalı olarak verilmiştir. Türkiye turizminde yaşanan zaman içinde yoğunlaşmayı da gösteren tabloda ilk dikkat çeken unsur, Haziran ayında normalin dışında gerçekleşen düşüş olmaktadır. Bu durum, yılın ilk 5 ayında Ankara, İstanbul ve Suriye sınırına yakın illerde gerçekleşen terör saldırılarının gecikmeli etkisi olarak değerlendirilebilir. Ağustos ayından sonraki ortalamanın altındaki düşüş de Rusya boykotunun bitişinin sonucudur.

\subsection{Kriz Sonrast}

2016 sonrası, turizmin ülke ekonomisi ve tanıtımı için önemi doğrultusunda, krizin aşılması ve toparlanma adına bir dizi önlem alınmıştır. Öncelikle tetikleyici unsurların giderilmesi için çalışmalar kapsamında, ilk olarak Rusya ile ardından (seyahat uyarısı yayınlayan) diğer önemli turist gönderen ülkeler ile ilişkilerin iyileştirilmesi yoluyla turist sayılarının artışa geçtiği görülmüştür. Son olarak ABD’nin de seyahat uyarısını yumuşatarak risk seviyesini düşürdüğünden daha önce bahsedilmiştir.

Endüstriyel anlamda da, turistik işletmelerin krizden korunması ve turist girişlerinin artırılması adına, acil kriz dönemi kabul edilen 2016 yılının hemen başında seyahat aracıları, havayolları ve konaklama işletmelerine önemli ölçüde (toplam yarım milyar Amerikan dolarından fazla) ekonomik katkı verilmesi kararlaştırılmıştır. Bu destek kapsamında ülkeye turist getiren işletmelerin teşviki amaçlanmış ve kredi ve hibe destekleri, borç erteleme ve teşvik ödenekleri yapılmıştır. Buna ek olarak Bakanlık belgeli konaklama ve deniz turizmi işletmeleri ihracatçı kapsamına alınmış, çevresel ve istihdam destekleri sunulmuştur. Krizden çıkış adına önemli turist gönderen ülke pazarlarında yitirilen güvenlik algısının yeniden oluşturulması adına da, uluslararası düzeyde tanıtım yoluyla, ülkede güvenlik sorununun giderildiği duyurulmuştur(Karabulut 2017). Tüm bu gelişmeler sonucu 2017 ve 2018, tetikleyici unsurlar tam olarak çözümlenememiş olsa bile, etkili halkla ilişkiler çalışması sayesinde uluslararası turist girişleri bakımından çok önemli artışlar kaydetmiş ve Türkiye turizminin dirençli yapısını göstermiştir.

\section{Sonuç ve Öneriler}

Bu çalışmada, Türkiye turizminin yakın geçmişte yaşadığı kriz, olay öncesi, öncül, acil ve toparlanma süreçleri içerisinde, nedenleri ve sonuçlarıyla birlikte incelenmiştir. Araştırmada, turizm krizinin turistik işletmeler, ülke ekonomisi ve tanıtımı için önemi ve sonuçları, turizm ekonomisi ilkeleri doğrultusunda çözümlenmiş; ayrıca, benzer turizm krizleri ve genel turizm krizi alan yazını ile karşılaştırmalı olarak incelenmiştir.

2016 turizm krizinin olay öncesi ve öncül dönemlerinde gelişen tetikleyici unsurları dikkate alındığında, alan yazınında verilen doğal afet ve salgın hastalık dışındaki tüm olayların gerçekleştiği görülmektedir. Komşu ülkelerde görülen iç savaş ve politik istikrarsızlık, bunların yayılma etkisi, sı̆̆ınmacı sorunu, terör, darbe girişimi, dış ilişkilerde yaşanan sorunlar ve seyahat uyarıları, kur dalgalanmaları, fiyat istikrarsızlığı ve turist pazarlarında güvenlik algısının yitirilmesini içeren gelişmeler (ve bunların dalgalanma etkisi) yaşanmıştır. Krize doğrudan neden olan ve en önemli sonuçları doğuran olay ise 
Türk hava sahasını ihlal eden Rus savaş uçağının düşürülmesi sonucu iki ülke arasındaki ilişkilerde yaşanan gerilim ve seyahat engeli olarak görülmektedir. Yine 2016 yılı boyunca yaşanan terör olayları ve darbe girişimi de, ülke imajına zarar vererek krizin süreğen hal almasına neden olmuştur.

Sonuç olarak yalnızca 2016 yılında, (bir önceki yıla göre) yaklaşı dörtte bir turist kaybı ve üçte bir gelir kaybı yaşanmıştır. Türkiye, uluslararası turist sayısı bakımından dünyada 6. sıradan bir anda 10. sıraya, turizm geliri bakımından ise 12. sıradan 17. sıraya gerilemiştir. 2010-2014 yıl1 \%7 gelişim projeksiyonunun devamı varsayımında, 2014-2018 yılları arasındaki toplam (doğrudan) turizm gelir kaybı 47,6 milyar Amerikan doları olmuştur. Bu kayıp ayrıca kendini yatırım, istihdam, toplam dışsatım ve ulusal gelir kaybında da göstermiştir.

Acil kriz döneminde, işletmelerin tepkisi fiyat indirimleri olmuştur. İşletmelere sağlanan parasal destek ve teşvikler ile dış ilişkilerde yaşanan iyileşme ve turist pazarlarında yapılan güvenlik kampanyaları sonucu 2017 ve 2018, uluslararası turist girişleri bakımından çok önemli artış gösterse de, fiyat indirimlerinin orta erimde yarattığı pazar baskısı sonucu, 2014 'te $\$ 742$ olan turist başına gelir 2018'de \$551'e kadar gerilemiştir. Yine turist sayısı bakımından 2018'de kriz atlatılmış görünse de, turizm geliri, turistik yatırımlar; ayrıca Türkiye turizminin (turist sayısı ve turizm geliri bakımından) uluslararası pazardaki payı ele alındığında krizi atlatamadığı görülmektedir.

2016 turizm krizinin, alan yazını ile uyumlu gelişen başka bir özelliği, Türk vatandaşı ve komşu / yakın ülkelerden olan turist girişlerinin daha az etkilenmesi olmuştur. $\mathrm{Bu}$ durumun güvenlik algisı ve iletişimindeki farklarda yattı̆̆ düşünülmektedir. Arka arkaya gelişen tetikleyici unsurlar bir dalgalanma etkisi yaratmış, turizm verileri hem acil, hem de gecikmiş tepkiler vermiştir. Yine 2016 yılı boyunca süreğen hal alan terör saldırılarının sona ermesi ve güvenliğin sağlanmasının, krizin kısa erimli olması ve atlatılması yönünde olumlu etkide bulunduğu açıktır. Ancak terörün etkilerini diğer tetikleyici unsurlardan yalıtarak incelemek mümkün değildir.

Ülke ekonomisi ve tanıtımı için yıkıcı etkiler sergilemekle birlikte, 2016 krizi turizm araştırmaları için önemli bir olay sayılmalıdır. Krizin yaşam süreçlerinin kaçınılmaz bir parçası olduğu kabul edilerek, krize neden olabilecek etkenler üzerinde kontrol sahibi olunduğu durumlarda önleme, diğer durumlarda da etkilerin öngörülmesine yönelik öncül plan ve stratejiler geliştirilmelidir. Krizi önlemeye ya da kısa erimde toparlanmaya yönelik uygulamalar ile krizi kontrol altına almaya yönelik eylemler ve halkla ilişkiler iletişimi, etkin bir kriz yönetimi için zorunlu görülmelidir. Krizin uzun erimli olarak ve çok boyutlu incelenmesi ile ulusal turizm yönetimi ve işletmeler Türkiye turizminin geleceği için yaşamsal çıkarımlarda bulunmalıdır. Bu doğrultuda, gelecekte olası krizler olası en düşük zararla atlatılabilir.

Tüm olumsuzluklara ve hatta ülkenin turizmden daha acil güvenlik sorunlarıyla karşı karşıya kalmasına rağmen, Türkiye turizminin başarılı bir kriz yönetimi ve benzer örneklerden daha kısa süreli ve etkili bir direnç gösterdiği sonucuna varılmışıtır.

Çalışma, yıllar içerisinde olayların izlenmesi ve krizin üç aşamalı değerlendirilebilmesi açısından, 2018 resmi verilerinin açıklanmasından sonra tamamlanmıştır. Bu açıdan zaman kısıtlaması yaşanmamıştır. İleride yapılacak araştırmalarda, Türkiye turizminin 2016 krizinden sonraki toparlanma süreci incelenebilir. 2017, 2018 ve ilk 9 aylık 2019 verileri, yakın gelecekte bütünsel bir toparlanma için umut vericidir. 
Yıldız, Ö., Işıldar, P. / Journal of Yasar University, 2020, 15/59, 407-425

\section{KAYNAKÇA}

Ağır, O. 2017. Türkiye'deki Suriyelilere Sağlanan Kamusal Hizmetlere Yönelik bir Değerlendirme. KAYSEM 11, (s. 111128).

BBC News Türkçe. 2015. “Mısır'da düşen Rus yolcu uçağından 'kurtulan yok'.”Erişim 21.09.2019. https://www.bbc.com/turkce/haberler/2015/10/151031_misir_rus_ucak.

BBC News Türkçe. 2016. "Almanya'dan vatandaşlarına Türkiye seyahati uyarısı.”Erişim 21.09.2019. https://www.bbc.com/turkce/haberler/2016/01/160112_almanya_sultanahmet_tepki.

BBC News Türkçe. 2017a. “Arap Baharı'nda devrilen liderlere ne oldu?”Erişim 21.09.2019. https://www.bbc.com/turkce/haberler-dunya-42232967.

BBC News Türkçe. 2017b. “Hollanda'dan seyahat uyarıs1, Türkiye'den iki nota.”Erişim 21.09.2019. https://www.bbc.com/turkce/haberler-dunya-39253964.

BBC News Türkçe. 2018. “10 Ekim Ankara Gar saldırısı davası sürecinde neler yaşandı?”Erişim 21.09.2019. https://www.bbc.com/turkce/haberler-turkiye-45010767.

Beirman, D. 2002. "Marketing of Tourism Destinations during a Prolonged Crisis: Israel and the Middle East." Journal of Vacation Marketing 8(2):167 - 176 .

BODER. 2016. “Abd Türkiye'ye Yine Seyahat Uyarısı Yapt1, 16 İli İşaret Etti.”Erişim 21.09.2019. http://www.boder.org/abd-turkiye-ye-yine-seyahat-uyarisi-yapti-16-ili-isaret-etti.html.

Burnett, J. J. 1998. “A strategic approach to managing crises.”Public Relations Review, 24(4): 475-488.

Cater, C. I. 2006. "Playing with risk? Participant perceptions of risk and management implications in adventure tourism.”Tourism Management 27(2): 317-325.

CNN. 2016. "September 11, 2001: Background and timeline of the attacks.”Erişim 14.07.2017. http://edition.cnn.com/2013/07/27/us/september-11-anniversary-fast-facts/index.html.

CNN. 2017. “July 72005 London Bombings Fast Facts.”Erișim 30.06.2017. http://edition.cnn.com/2013/11/06/world/europe/july-7-2005-london-bombings-fast-facts/index.html.

CNN Türk. 2017. “İsviçre'den vatandaşlarına 'Türkiye'ye seyahat' uyarısı.”Erişim 21.09.2019. https://www.cnnturk.com/dunya/isvicreden-vatandaslarina-turkiyeye-seyahat-uyarisi.

CNN Türk. 2018.“10 Ekim'de öldürülenler katliamın 3. yılında Ankara Garı önünde anıldı.”Erişim 21.09.2019. https://www.cnnturk.com/turkiye/10-ekimde-oldurulenler-katliamin-3-yilinda-ankara-gari-onunde-anildi.

Cumhuriyet. 2016a. “ABD'den vatandaşlarına Türkiye uyarısı.”Erişim 21.09.2019. http://www.cumhuriyet.com.tr/haber/dunya/592622/ABD_den_vatandaslarina_Turkiye_uyarisi.html.

Cumhuriyet. 2016b. "Kanada'dan Türkiye'ye seyahat uyarısı kararı”.Erişim 21.09.2019. http://www.cumhuriyet.com.tr/haber/dunya/583785/Kanada_dan_Turkiye_ye_seyahat_uyarisi_karari.html.

Downs, A. 1972. "Up and down with ecology - the issue attention cycle."Public Interest, 28: 38-50.

DW. 2018a. “Almanya'dan Türkiye'ye seyahat edeceklere yeni uyarı.”Erişim 21.09.2019. https://www.dw.com/tr/almanyadan-t\%C3\%BCrkiyeye-seyahat-edeceklere-yeni-uyar\%C4\%B1/a-46018322.

DW. 2018b. "Yedi yılda bir ülkenin çöküşü: Suriye.”Erişim 21.09.2019. https://www.dw.com/tr/yedi-y\%C4\%B1lda-bir\%C3\%BClkenin-\%C3\%A7\%C3\%B6k\%C3\%BC\%C5\%9F\%C3\%BC-suriye/a-42979799.

Faulkner, B. 2001. "Towards a framework for tourism disaster management.”Tourism Management 22: 135-147.

Göçen, S., Yirik, Ș. ve Yılmaz, Y. 2011. “Türkiye’de Krizler ve Krizlerin Turizm Sektörüne Etkileri.”Suleyman Demirel University The Journal of Faculty of Economics and Administrative Sciences 16(2): 493-509.

Gümüş, N. T. 2015. “Mülteci krizi nasıl patladı.”Erişim 21.09.2019. http://www.hurriyet.com.tr/yazarlar/nilgun-tekfidangumus/multeci-krizi-nasil-patladi-30002960.

Haber Turk. 2016. Erişim 21.09.2016. https://www.haberturk.com/olay/15-temmuz.

Hajibaba, H., Gretzel, U., Leisch, F. Ve Dolnicar, S. 2015. “Crisis-resistant tourists.”Annals of Tourism Research 53: 4660.

Hall, C. 2002. “Travel Safety, Terrorism and the Media: The Significance of the Issue-Attention Cycle.”Current Issues in Tourism 5(5): 458-466.

Heath, R. 1998. Crisis management for managers and executives. London: Financial Times Management.

Henderson, J. C. 2007. Managing Tourism Crises - A volume in The Management of Hospitality and Tourism Enterprises. Oxford OX2 8DP, UK: Butterworth-Heinemann, Elsevier Inc.

Hürriyet. 2016a. "5 soruda Ankara Kızılay terör saldırısı 13.03.2016.”Erişim 21.09.2019. http://www.hurriyet.com.tr/gundem/5-soruda-ankara-kizilay-teror-saldirisi-13-03-2016-40068403.

Hürriyet. 2016b. “Son dakika haberi: İşte hain saldırıdaki yılanın başı! Tek kol...”Erişim 21.09.2019. http://www.hurriyet.com.tr/gundem/son-dakika-haberi-ataturk-havalimanindaki-saldiridan-aci-haberler-gelmeyedevam-ediyor-40123515.

Hürriyet. 2018. "Merasim Sokak saldırısı davasında 6 sanığa ağırlaştırılmış ömür boyu hapis.”Erişim 21.09.2019. http://www.hurriyet.com.tr/merasim-sokak-saldirisi-davasinda-6-saniga-agir-40952128. 
Yıldız, Ö., Işı1ldar, P. / Journal of Yasar University, 2020, 15/59, 407-425

İçöz, O. 2001. Turizm İşletmelerinde Pazarlama, İlkeler ve Uygulamalar (2 b.). Ankara: Turhan Kitabevi.

İçöz, O. 2005. Turizm Ekonomisi (3 b.). Ankara: Turhan Kitabevi.

İçöz, O., Var, T. ve İlhan, İ. 2009. Turizm Planlaması ve Politikası - Turizmde Bölgesel Planlama (2 b.). Ankara: Turhan Kitabevi.

Karabulut, E. 2017. 2015/2016 Kriz Döneminde Türkiye Turizmi. Antalya: Turizmdatabank.

Kozak, M., Crotts, J. ve Law, R. 2007. “The Impact of the Perception of Risk on International Travellers.”International Journal of Tourism Research 9: 233-242.

Kozak, M., Kozak, N. K. ve Kozak, N. 2015. Genel Turizm - Illkeler, Kavramlar(17 b.). Ankara: Detay Yayınc1lık.

Küçükaltan, D., Tükeltürk, Ş. A. ve Çiftçi, G. 2015. Otel İşletmelerinde Kriz Yönetimi. Ankara: Detay Yayıncılık.

Maser, B.ve Weiermair, K. 1998. "Travel Decision-Making: From the Vantage Point of Perceived Risk and Information Preferences.” Journal of Travel \& Tourism Marketing 7(4): 107-121.

Nordkvist Öman, E. 2016. Tourism in an era of migration - A case study with a focus on the impacts of a crisis, from a consumer perspective. Bachelor thesis, Linnaeus University, Sweden.

OECD. 2018. “OECD Tourism Trends and Policies 2018. Paris: OECD Publishing.”Erişim 21.09.2019.http://dx.doi.org/10.1787/tour-2018-en.

Olalı, H. ve Timur, A. 1988. Turizm Ekonomisi. İzmir: Ofis Ticaret Matbaacılık.

Ooi, C., Hooy, C. ve Som, A. 2013. “Tourism Crises And State Level Tourism Demand In Malaysia.” International Journal of Business and Society 14(3): 376 - 389.

Öksüz, B. ve Batu, M. 2017. “Kriz İletişimi ve Turizm: 2016 Yılı Terör Saldırıları.”Egemia 1: 85-108.

Parsons, W. 1996. “Crisis management.”Career Development International 1(5): $26-28$.

Plog, S. C. 1974. "Why Destination Areas Rise and Fall in Popularity."Cornell Hotel and Restaurant Administration Quarterly 14(4): 55-58.

Procopio, C. H. ve Procopio, S. T. 2007. "Do you know what it means to miss New Orleans? Internet communication, geographic community, and social capital in crisis.”Journal of Applied Communication Research 35(1): 67-87.

REFTUR. 2016. “Almanya'dan Türkiye'ye Seyahat Uyarısı Güncellemesi.”Erişim 21.09.2019. http://www.reftur.com/page/almanyadan-turkiyeye-seyahat-uyarisi-guncellemesi.

Ritchie, B. W. 2004. "Chaos, crises and disasters: a strategic approach to crisis management in the tourism industry.”Tourism Management 25: 669-683.

Saha, S. ve Yap, G. 2013. "The Moderation Effects of Political Instability and Terrorism on Tourism Development: A Cross-Country Panel Analysis.” Journal of Travel Research 20(10): 1-13.

Sarı, H. 2018. "Birleşik Krallık'tan Türkiye'ye seyahat uyarısı: Suriye sınırından ve Diyarbakır'dan uzak durun.”Erişim 21.09.2019. http://www.hurriyet.com.tr/birlesik-kralliktan-turkiyeye-seyahat-uyarisi-40710662.

Seabra, C., Abrantes, J. ve Kastenholz, E. 2014. "The influence of terrorism risk perception on purchase involvement and safety concern of international travellers.” Journal of Marketing Management 30(9-10): 874-903.

Sönmez, S. ve Graefe, A. 1996. Risk Perceptions of U.S. International Vacation Travelers. Travel and Tourism Research Association (ed.). It 5. Showtime for Tourism: New Products, Markets arid Technologies, Proceedings 27th Annual Conference, Lexington, KY Travel and Tourism Research Association, s. 192-200.

Sönmez, S. ve Graefe, A. 1998. "Influence Of Terrorism Risk On Foreign Tourism Decisions.”Annals of Tourism Research 25(1): 112-144.

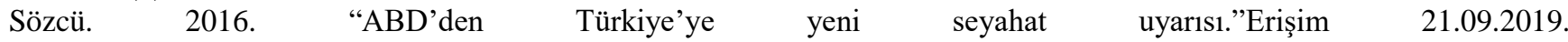
https://www.sozcu.com.tr/2016/dunya/abdden-turkiyeye-yeni-seyahat-uyarisi-1294103/.

$\begin{array}{lllll}\text { TCMB. } 2019 . & \text { "Ödemeler } & \text { Dengesi } & \text { İstatistikleri”.Erişim } & \text { 2019.2019. }\end{array}$ https://www.tcmb.gov.tr/wps/wcm/connect/TR/TCMB+TR/Main+Menu/Istatistikler/Odemeler+Dengesi+ve+Ilgili+I statistikler/Odemeler+Dengesi+Istatistikleri/.

T.C. Kültür ve Turizm Bakanlığı. 2019. Türkiye Cumhuriyeti Kültür ve Turizm Bakanlı̆̆l. Erişim 01.08.2019. https://yigm.ktb.gov.tr/TR-9851/turizm-istatistikleri.html.

Timur, A. 2014. Turizm Ekonomisi. Ders Notları. İzmir.

TUIK. 2019. “Turizm İstatistikleri.”Erişim01.09.2019. http://www.tuik.gov.tr/PreTablo.do?alt_id=1072.

Turizm Gazetesi. 2013. “Ülkelerin Türkiye'ye Seyahat Uyarıları Artıyor.”Erişim 21.09.2019. https://www.turizmgazetesi.com/news.aspx?id=70449.

turizmdebusabah. 2016. 20.07.2016 tarihinde turizmdebusabah.com adresinden alındı.

Um, S. ve Crompton, J. 1990. "Attitude determinants in tourism destination choice.”Annals of Tourism Research 17(3): 432-448.

UNWTO. 2011. “UNWTO Tourism Highlights, 2011 Edition.”Erişim 23.09.2019. https://www.eunwto.org/doi/book/10.18111/9789284413935.

UNWTO. 2012. “UNWTO Tourism Highlights, 2012 Edition.”Erişim 23.09.2019. https://www.eunwto.org/doi/pdf/10.18111/9789284414666.

UNWTO. 2013. “UNWTO Tourism Highlights, 2013 Edition.”Erişim 23.09.2019. https://www.eunwto.org/doi/pdf/10.18111/9789284415427. 
Yıldız, Ö., Işıldar, P. / Journal of Yasar University, 2020, 15/59, 407-425

UNWTO. 2014. “UNWTO Tourism Highlights, 2014 Edition.”Erişim 23.09.2019. https://www.eunwto.org/doi/pdf/10.18111/9789284416226.

UNWTO. 2015. “UNWTO Tourism Highlights, 2015 Edition.”Erişim 23.09.2019. https://www.eunwto.org/doi/pdf/10.18111/9789284416899.

UNWTO. 2016. “UNWTO Tourism Highlights 2016 Edition.”Erişim 19.07.2016. http://www.eunwto.org/doi/pdf/10.18111/9789284418145 adresinden alındı.

UNWTO. 2017. "UNWTO Tourism Highlights, 2017 Edition.”Erişim 23.09.2019. https://www2.unwto.org/publication/unwto-tourism-highlights-2017.

UNWTO. 2018. "UNWTO Tourism Highlights, 2018 Edition.”Erişim 23.09.2019.https://www.eunwto.org/doi/pdf/10.18111/9789284419876.UNWTO. 2019. "International Tourism Highlights, 2019 Edition.”Erişim 23.09.2019. https://www.e-unwto.org/doi/pdf/10.18111/9789284421152.

US Department of State. “2019. Turkey Travel Advisory.”Erişim 21.09.2019. https://travel.state.gov/content/travel/en/traveladvisories/traveladvisories/turkey-travel-advisory.html.

Varlı, A. 2016. “Almanlar rotadan Türkiye'yi çıkardı.”Erişim 21.09.2019. Hürriyet: http://www.hurriyet.com.tr/ekonomi/almanlar-rotadan-turkiyeyi-cikardi-40047633.

VOA. 2018. “ABD-Türkiye Hattında Seyahat Geriliminde İkinci Perde.”Erişim 21.09.2019. https://www.amerikaninsesi.com/a/abd-turkiye-hattinda-seyahat-geriliminde-ikinci-perde/4204911.html.

Wahab, S., Crampon, L. ve Rothfield, L. 1976. Tourism marketing. London: Tourism International Press.

Yeni Hayat. 2016. “Terör saldırıları nedeniyle Türkiye'ye seyahat uyarısı.”Erişim 21.09.2019. https://yenihayat.de/2016/12/11/teroer-saldirilari-nedeniyle-tuerkiyeye-seyahat-uyarisi.

yolculuk. 2016. “Almanya'dan vatandaşlarına 'Türkiye'ye seyahat etmeyin' uyarısı.”Erişim 21.09.2019. https://gazeteyolculuk.net/almanyadan-vatandaslarina-turkiyeye-seyahat-etmeyin-uyarisi. 